\title{
Chemical characterization and source apportionment of submicron aerosols measured in Senegal during the 2015 SHADOW campaign
}

\author{
Laura-Hélèna Rivellini ${ }^{1,2}$, Isabelle Chiapello ${ }^{2}$, Emmanuel Tison ${ }^{1}$, Marc Fourmentin $^{3}$, Anaïs Féron ${ }^{4}$, \\ Aboubacry Diallo ${ }^{5}$, Thierno N'Diaye ${ }^{5}$, Philippe Goloub ${ }^{2}$, Francesco Canonaco ${ }^{6}$, André Stephan Henry Prévôt ${ }^{6}$, and \\ Véronique Riffault ${ }^{1}$ \\ ${ }^{1}$ IMT Lille Douai, Univ. Lille, SAGE - Département Sciences de l'Atmosphère et Génie de l'Environnement, \\ 59000 Lille, France \\ ${ }^{2}$ Univ. Lille, CNRS, UMR8518 - LOA - Laboratoire d'Optique Atmosphérique, 59000 Lille, France \\ ${ }^{3}$ Laboratoire de Physico-Chimie de l'Atmosphère, Université du Littoral Côte d'Opale, Dunkerque, 59140, France \\ ${ }^{4}$ Laboratoire Interuniversitaire des Systèmes Atmosphériques, CNRS - Université Paris Est Créteil - Université Paris Diderot, \\ Créteil, 94010, France \\ ${ }^{5}$ Institut de Recherche pour le Développement, M'Bour, Senegal \\ ${ }^{6}$ Laboratory of Atmospheric Chemistry, Paul Scherrer Institute, 5232 Villigen, Switzerland
}

Correspondence to: Véronique Riffault (veronique.riffault@imt-lille-douai.fr)

and Laura-Hélèna Rivellini (laura.rivellini@imt-lille-douai.fr)

Received: 5 January 2017 - Discussion started: 27 February 2017

Revised: 19 July 2017 - Accepted: 20 July 2017 - Published: 1 September 2017

\begin{abstract}
The present study offers the first chemical characterization of the submicron $\left(\mathrm{PM}_{1}\right)$ fraction in western Africa at a high time resolution, thanks to collocated measurements of nonrefractory (NR) species with an Aerosol Chemical Speciation Monitor (ACSM), black carbon and iron concentrations derived from absorption coefficient measurements with a 7-wavelength Aethalometer, and total $\mathrm{PM}_{1}$ determined by a TEOM-FDMS (tapered element oscillating microbalance-filtered dynamic measurement system) for mass closure. The field campaign was carried out over 3 months (March to June 2015) as part of the SHADOW (SaHAran Dust Over West Africa) project at a coastal site located in the outskirts of the city of Mbour, Senegal. With an averaged mass concentration of $5.4 \mu \mathrm{g} \mathrm{m}^{-3}$, levels of NR $\mathrm{PM}_{1}$ in Mbour were 3 to 10 times lower than those generally measured in urban and suburban polluted environments. Nonetheless the first half of the observation period was marked by intense but short pollution events (NR $\mathrm{PM}_{1}$ concentrations higher than $15 \mu \mathrm{g} \mathrm{m}^{-3}$ ), sea breeze phenomena and Saharan desert dust outbreaks $\left(\mathrm{PM}_{10}\right.$ up to $\left.900 \mu \mathrm{g} \mathrm{m}^{-3}\right)$. During the second half of the campaign, the sampling site was mainly under the influence of marine air masses. The air masses on days under continental and sea breeze influences
\end{abstract}

were dominated by organics (36-40\%), whereas sulfate particles were predominant $(40 \%)$ for days under oceanic influence. Overall, measurements showed that about threequarters of the total $\mathrm{PM}_{1}$ were explained by $\mathrm{NR} \mathrm{PM}_{1}, \mathrm{BC}$ (black carbon) and Fe (a proxy for dust) concentrations, leaving approximately one-quarter for other refractory species. A mean value of $4.6 \%$ for the $\mathrm{Fe} / \mathrm{PM}_{1}$ ratio was obtained. Source apportionment of the organic fraction, using positive matrix factorization (PMF), highlighted the impact of local combustion sources, such as traffic and residential activities, which contribute on average to $52 \%$ of the total organic fraction. A new organic aerosol (OA) source, representing on average $3 \%$ of the total OA fraction, showed similar variation to nonrefractory particulate chloride. Its rose plot and daily pattern pointed to local combustion processes, i.e., two open waste-burning areas located about 6 and $11 \mathrm{~km}$ away from the receptor site and to a lesser extent a traditional fish-smoking location. The remaining fraction was identified as oxygenated organic aerosols (OOA), a factor that prevailed regardless of the day type (45\%) and was representative of regional (approximately three-quarters) but also local (approximately one-quarter) sources due to enhanced photochemical processes. 


\section{Introduction}

Atmospheric aerosols play a key role in the Earth's radiative forcing, by interacting with incoming solar and outgoing terrestrial radiations (direct effect) and influencing cloud formation, growth and lifetime (indirect effects). Important uncertainties related to such effects remain, as reported in the IPCC reports (IPCC, 2007, 2013). Besides, several epidemiological and toxicological studies (Brook et al., 2004; Kelly and Fussell, 2012) also highlight the sanitary impacts of particulate matter (PM) depending on its size, chemical composition and exposure time. In 2012, around 3.7 million deaths were attributed to cardiovascular and respiratory diseases caused by outdoor PM exposure (Brauer et al., 2012). As a response, in 2006 the World Health Organization (WHO) established air quality thresholds for PM: a daily average of 25 (50) $\mu \mathrm{g} \mathrm{m}^{-3}$ and a mean annual limit of $10(20) \mu \mathrm{g} \mathrm{m}^{-3}$ for $\mathrm{PM}_{2.5}$, i.e., $\mathrm{PM}$ with diameter $<2.5 \mu \mathrm{m}\left(\mathrm{PM}_{10}\right)(\mathrm{WHO}, 2006)$. During recent decades, high-time-resolution monitoring instruments have been implemented in Europe within the ACTRIS (Aerosols, Clouds, and Trace gases Research Infrastructure network) program, in America with the IMPROVE (Interagency Monitoring of Protected Visual Environments) network (Prenni et al., 2016; Schurman et al., 2015) or more recently in Asia, in order to better characterize fine particles. Yet the African continent remains poorly documented in terms of particulate pollution.

Several studies in western Africa (mostly sub-Saharan regions) have focused on the coarse fraction, since this area is strongly influenced by natural sources, especially the Sahara, which injects high amounts of mineral aerosols into the atmosphere (e.g., Chiapello et al., 1995). Among field campaigns, a large effort was performed on aerosol measurements during the AMMA (African Monsoon Multidisciplinary Analysis) program carried out between 2002 and 2010, with intensive observation periods in 2006 (Redelsperger et al., 2006). During the months of JanuaryFebruary (dry season) the transport of desert dust (DD) and biomass burning (BB) aerosols were observed to occur into two layers, one dominated by DD close to the surface $(<1 \mathrm{~km})$ and one containing BB aerosols that is located at a higher altitude, between 2 and $4 \mathrm{~km}$ (Haywood et al., 2008; Osborne et al., 2008). During one of the AMMA special observing periods (SOPs), in February 2006, a chemical characterization of particles at the ground level was performed near Mbour (Senegal) using filter sampling and individual particle analysis (Deboudt et al., 2010; Flament et al., 2011). The analysis evidenced both internal and external mixing of DD, sea salt (SS) and carbonaceous aerosols (Deboudt et al., 2010) within the surface layer. The compositions of the coarse $(2-10 \mu \mathrm{m})$ and fine $(<2 \mu \mathrm{m})$ fractions were established at the surface; DD dominated the coarse fraction while organic matter was the major constituent of the fine one. Similar analyses were performed on samples collected during aircraft flights (Formenti et al., 2008) to determine the chemical composition of aerosols at different altitudes. The altitude layer was mainly composed of BB and DD external mixture (Chou et al., 2008; Hand et al., 2010). From January to March 2006 (AMMA SOP-0), several types of events from mixtures of DD and BB aerosols to pure mineral dust events were identified based on column aerosol retrievals from AERONET sun and/or sky photometer measurements in Mbour, Senegal (Derimian et al., 2008). Other field campaigns such as POLCA (POLlution des Capitales Africaines: the Pollution of African Capitals) highlighted the presence of anthropogenic sources of aerosols linked to the strong demographic growth, limited traffic pollution regulations and traditional activities such as slash-and-burn cultivation that generate huge amounts of $\mathrm{BB}$ aerosols (Liousse et al., 2010). Its focus was rather on the chemical characterization of $\mathrm{PM}_{2.5}$, especially black carbon (Doumbia et al., 2012), and the impact on health (Val et al., 2013). Nevertheless, to the best of our knowledge, only one other study has performed online and real-time chemical characterization of major $\mathrm{PM}_{1}$ constituents on the African continent. It was conducted over 1 year in Welgegund, South Africa, at a site influenced by anthropogenic sources and devoid of mineral dust or marine contribution (Tiitta et al., 2014). Their results have shown that the submicron fraction was dominated by organic and sulfate species, with a chemical composition similar to those encountered in megacities such as Beijing (Sun et al., 2012) and Mexico City (Salcedo et al., 2006) as well as Pittsburgh (Zhang et al., 2005). Such a pattern differs strongly from those recently measured in European urban cities, where the main submicron pollutants are organic and nitrate species (Petit et al., 2015; Schlag et al., 2016).

In this study we offer the first insight of a real-time, continuous and long-term chemical characterization of $\mathrm{PM}_{1}$ in western Africa, performed in Mbour, Senegal, from March to June 2015 as part of the first intensive observation period (IOP-1) of the SHADOW (SaHAran Dust Over West Africa) field campaign. An Aerosol Chemical Speciation Monitor (ACSM) was chosen for the quantification and chemical characterization of nonrefractory submicron particles, the instrument being better suited for unattended and long-term monitoring. Parallel measurements of $\mathrm{BC}$ and total $\mathrm{PM}_{1}$ allowed for mass closure. This paper reports the chemical composition of the submicron fraction and the temporal behavior of particulate species. The sources and processes responsible for the concentrations encountered at the Mbour site over the period have been assessed using source-receptor modeling as well as dynamic meteorological measurement parameters and back-trajectory analyses. 


\section{Instrumentation and methods}

\subsection{Site description and the SHADOW campaign}

The sampling site is located within the Institut de Recherche et Développement (IRD) facility in Mbour $\left(14^{\circ} 23^{\prime} 38^{\prime \prime} \mathrm{N}\right.$, $\left.16^{\circ} 57^{\prime} 32^{\prime \prime} \mathrm{W}\right)$, Senegal. This site, located near the seashore $80 \mathrm{~km}$ south of Dakar (Fig. 1), is known to be under the influence of Saharan dust, sea salt and biomass burning during part of the dry season. The site may also be affected by regional anthropogenic emissions from surrounding cities including Mbour and Dakar, and from traditional fish-smoking activities and open waste-burning areas. These potential aerosol source locations are reported in Fig. 1. The Mbour station, as part of the international AERONET network (Holben et al., 1998), is routinely equipped with active and passive remote sensing instruments for cloud, aerosol and meteorological monitoring (CIMEL sun/sky photometer, CIMEL microlidar, flux meters and a weather station). Since the AMMA campaigns in 2006, Mbour is also one of the three ground-based stations of the "Sahelian Dust Transect" where $\mathrm{PM}_{10}$ mass concentrations are measured continuously (every $5 \mathrm{~min}$ ) thanks to a tapered element oscillating microbalance (TEOM; Marticorena et al., 2010; Kaly et al., 2015).

The main objectives of SHADOW are to better determine the physical and chemical properties of particles in this region, largely influenced by high concentrations, and to establish a link between them, the atmospheric dynamics, and the aerosol load and optical properties. A large panel of high-performance instruments has therefore been added to the AERONET station (Holben et al., 1998) implemented in Mbour since 1996 (Derimian et al., 2008). Optical and microphysical aerosol measurements (results not presented) were also performed on-site by active and passive remotesensing instruments, such as the LiLAS lidar (Bovchaliuk et al., 2016; Veselovskii et al., 2016) and a PLASMA airborne sun photometer (Karol et al., 2013). PM $_{10}$ in situ optical measurements at the surface were carried out by a monowavelength Aethalometer and a nephelometer. Fine and coarse particle size distributions were recorded by a GRIMM optical particle counter, while ground and airborne filter sampling were collected through a four-stage DEKATI cascade impactor to be analyzed offline by individual particle analysis. A Doppler lidar was implemented to improve our understanding of the atmospheric dynamics between the surface and up to $2-3 \mathrm{~km}$ over the IRD station in order to provide more accurate micrometeorological information.

The online chemical composition measurements presented here were acquired during IOP-1, which took place from 20 March to 22 June 2015. Results discussed in this paper focus on the chemical characterization of surface $\mathrm{PM}_{1}$. The instruments presented hereafter were set up in an airconditioned room located underneath the flat roof of the IRD main building. Colocated wind speed and direction were measured by an ultrasonic anemometer (model USA-1, METEK GmbH) deployed on the rooftop (about $12 \mathrm{~m}$ above ground).

\subsection{Instrumentation}

\subsubsection{ACSM}

The chemical characterization of nonrefractory submicron particles $\left(\mathrm{NR} \mathrm{PM}_{1}\right)$, i.e., material vaporizing around $600^{\circ} \mathrm{C}$ under close-to-vacuum conditions, was performed online and in real time every 30 min by an ACSM (Aerodyne Research Inc.). This instrument is based on the same principle as the aerosol mass spectrometers (AMSs), without providing size distribution information. A full description of the instrument is presented in $\mathrm{Ng}$ et al. (2011a). Basically it is composed of an aerodynamic lens that focuses the particle beam (with vacuum aerodynamic diameters below $1 \mu \mathrm{m}$ ) and directs it through three vacuum chambers, the last one being a detection chamber in which particles are vaporized by impaction on a surface heated at $600^{\circ} \mathrm{C}$. Nonrefractory species, such as organic matter $(\mathrm{OM})$, sulfate $\left(\mathrm{SO}_{4}\right)$, nitrate $\left(\mathrm{NO}_{3}\right)$, ammonium $\left(\mathrm{NH}_{4}\right)$ and nonrefractory chloride $(\mathrm{Chl})$, are vaporized at this temperature and then ionized by electron impact $(70 \mathrm{eV})$. The above-mentioned names of the different NR species correspond to the sum of all $\mathrm{m} / \mathrm{z}$ fragments related to one given species in the fragmentation table (Allan et al., 2004), i.e., $\mathrm{H}_{0 \leq x \leq 2} \mathrm{~S}_{0 \leq y \leq 1} \mathrm{O}_{0 \leq z \leq 4}$ for sulfate, $\mathrm{NH}_{0 \leq x \leq 2}$ for ammonium, $\mathrm{NO}_{0 \leq x \leq 2}$ and $\mathrm{HNO}_{3}$ for nitrate, and $\mathrm{H}_{0 \leq x \leq 1} \mathrm{Cl}$ for chloride. Particles are then detected by mass spectrometry thanks to a residual gas analyzer (RGA). Because of a simple operating system and the use of a quadrupole mass spectrometer, the instrument has lower time resolution and sensitivity but remains better suited for long-term monitoring. A $\mathrm{PM}_{2.5}$ cut-off inlet (URG Cyclone 2000-30EH, Chapel Hill, NC, USA) was placed on the roof at the entrance of the sampling line with a primary flow of $3 \mathrm{~L} \mathrm{~min}^{-1}$ ? and vertically connected to the instrument. A Nafion dryer (PD-200T-12 MPS, Perma Pure) upstream of the inlet reduces the sample relative humidity (RH). Particle losses were evaluated using the particle loss calculator (von der Weiden et al., 2009) and were less than $2 \%$ between $50 \mathrm{~nm}$ and $1 \mu \mathrm{m}$.

Several calibrations were performed with ammonium nitrate, ammonium sulfate and ammonium chloride individual solutions (at $0.005 \mathrm{~mol} \mathrm{~L}^{-1}$ in purified water) prior to IOP-1. An average of all previous calibrations with this instrument gives a mean $\mathrm{NO}_{3}$ response factor $(\mathrm{RF})$ of $3.63 \times 10^{-11}$ and mean relative ionization efficiencies (RIEs) of 5.72, 0.58 and 2.26 for ammonium, sulfate and chloride, respectively (see Supplement, Fig. S1a-e, and Zhang et al., 2017, for more details). Organic and nitrate RIE default values of 1.4 and 1.1, respectively, were used (Canagaratna et al., 2007). Detection limits in micrograms per cubic meter $\left(\mu \mathrm{g} \mathrm{m}^{-3}\right)$ were determined by $\mathrm{Ng}$ et al. (2011a) to be 0.284 for ammonium, 0.148 for organic matter, 0.024 for sulfate, 0.012 for nitrate 
(a)
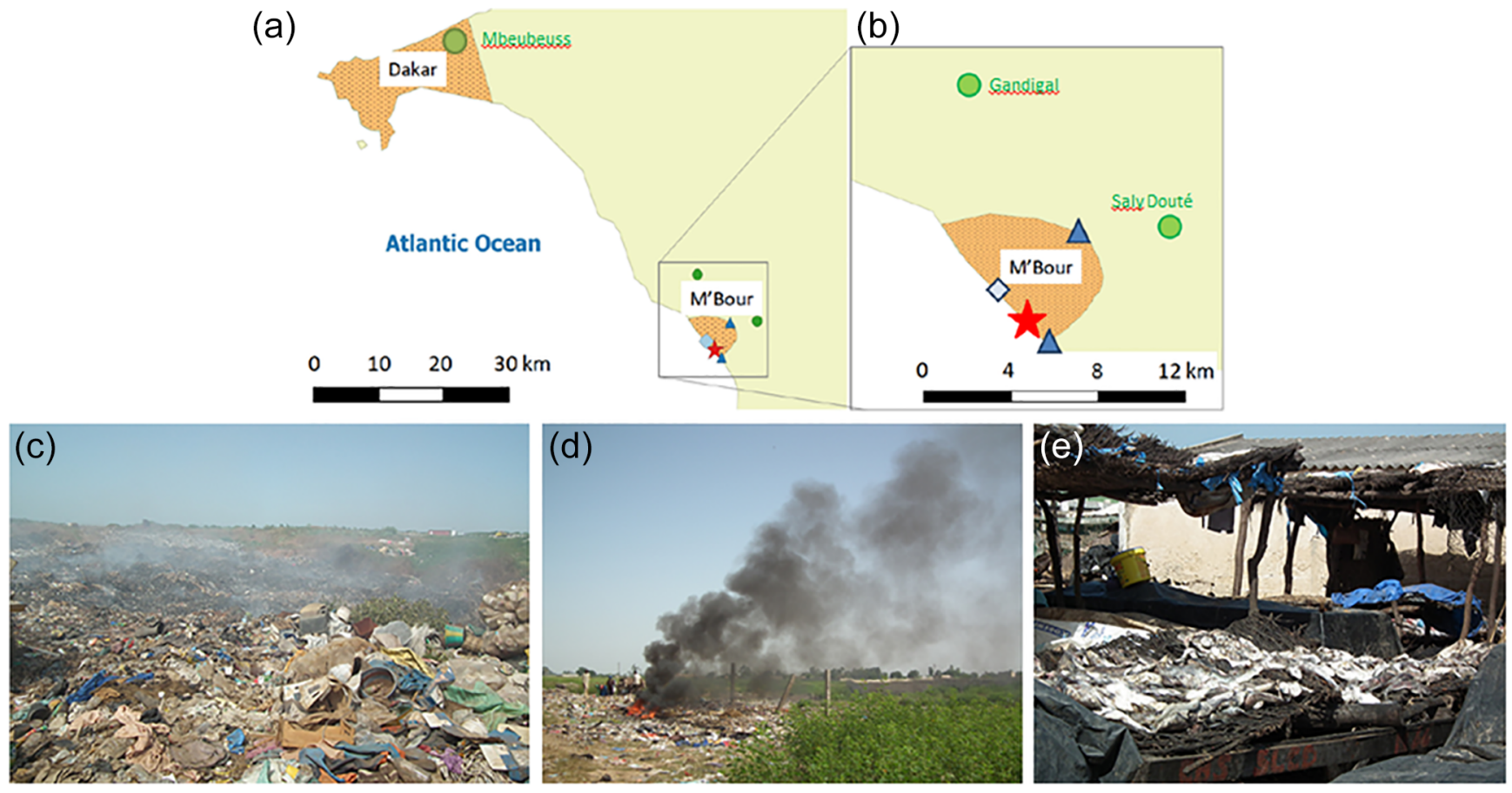

Figure 1. (a) Dakar and Mbour locations with city delimitations in orange and (b) local sources located around the IRD sampling site (red star), with open waste-burning areas (green circles), fish-smoking sites (blue triangles) and the Mbour port (light blue diamond). (ce) Photographs of a smoldering fire in the Gandigal open waste-burning area, a flaming fire in the Saly Douté open waste-burning area, and a fish-smoking location (drying stage) in the suburb of Mbour.

and 0.011 for chloride. It must be noted, however, that the uncertainties of mass concentrations with aerosol mass spectrometers are estimated at $20-35 \%(2 \sigma)$ for the total mass (Bahreini et al., 2009). Furthermore, Crenn et al. (2015) reported reproducibility-related uncertainties of Q-ACSM concentration measurements of $9,15,19,28$ and $36 \%$ for NR $\mathrm{PM}_{1}$, nitrate, organic matter, sulfate and ammonium, respectively, during an intercomparison that involved 13 Q-ACSMs in the Paris area during springtime. In addition to the relative ion transmission efficiency correction applied using a naphthalene internal standard, the collection efficiency (CE) due to particle losses induced by an incomplete vaporization and/or transmission through the aerodynamic lens was also determined for the whole dataset. Those parameters are mainly influenced by particle shape (size, sphericity) and acidity, ammonium nitrate fraction and $\mathrm{RH}$ in the sampling line. Middlebrook et al. (2012) have developed a correction algorithm based on AMS datasets which is applied on ACSM mass concentrations and which considers both RH and aerosol chemical composition to obtain a time-dependent correction of $\mathrm{CE}$ values ranging from 0.45 to 0.83 (Fig. S1f). Nonetheless, due to the presence of the Nafion dryer at the entrance of the instrument, no RH corrections were necessary as RH values were below $30 \%$. A minor fraction (3.2\%) of the data was excluded from the dataset due to unstable pa- rameters, which were generally observed after restarting the instrument following power outages.

\subsubsection{AE33 Aethalometer}

Real-time measurements of aerosol absorption were performed every minute by a seven-wavelength $(370,470,520$, $590,660,880$ and $950 \mathrm{~nm}$ ) Aethalometer (AE33, Magee Scientific Inc.). The instrument was equipped with a $\mathrm{PM}_{1} \mathrm{im}-$ pactor inlet (BGI model SCC-0.732, Waltham, MA, USA) and sampled at $5 \mathrm{~L} \mathrm{~min}^{-1}$. The Aethalometer principle is based on the measurement of light transmission through a filter onto which aerosols deposit. The attenuation is then converted into an aerosol absorption coefficient $\sigma_{\text {aer }}$ for each wavelength. $\mathrm{BC}$ concentrations are retrieved by applying a specific mass absorption cross section of $7.77 \mathrm{~m}^{2} \mathrm{~g}^{-1}$ to the absorption coefficient at $880 \mathrm{~nm}$. The AE33 instrument uses internal corrections based on the Weingartner et al. (2003) algorithm to account for multiple scattering by the filter and a dual spot technology (Drinovec et al., 2015) to compensate the loading effect. Even if DD absorption is limited at $880 \mathrm{~nm}$, its occurrence in high concentrations on-site might cause an overestimation of $\mathrm{BC}$ concentrations derived from absorption measurements. The method developed by Fialho et al. $(2005,2006,2014)$ was used to correct BC concentration data from mineral dust interference. This method is further explained in Sect. II.2.3.2. 


\subsubsection{Other instruments}

To achieve mass closure in the submicron fraction and account for the expected refractory material (mineral dust and sea salt), ambient air was sampled at $16.7 \mathrm{~L} \mathrm{~min}^{-1}$ through a $\mathrm{PM}_{10}$ inlet (Thermo Fisher Scientific Inc.) mounted on a $\mathrm{PM}_{1}$ cyclone (SCC 2.229, BGI Inc., Waltham, MA). Gravimetric measurements of the total mass concentrations were performed every 6 min using a TEOM operating at a temperature of $30^{\circ} \mathrm{C}$ and equipped with a filtered dynamic measurement system (TEOM-FDMS 1405-F, Thermo Scientific) that can account for semivolatile material by maintaining temperature under $30^{\circ} \mathrm{C}$ and relative humidity below $25 \%$, as described by Grover et al. (2005). Some data had to be discarded, mainly due to high temperatures encountered during dust events leading to FDMS failure to maintain proper operating conditions.

Micrometeorological parameters (wind speed and direction) at the surface $(\sim 10 \mathrm{~m}$ high) were obtained from $15 \mathrm{~min}$ accumulation (at $20 \mathrm{~Hz}$ ) with an ultrasonic anemometer (model USA-1 by METEK $\mathrm{GmbH}$ ) with a resolution of $0.01 \mathrm{~m} \mathrm{~s}^{-1}$ and $1^{\circ}$, respectively. A weather station (Campbell Scientific) provided precipitation, $\mathrm{RH}$ and temperature data every $10 \mathrm{~min}$.

\subsection{Analysis strategy}

\subsubsection{Classification of air masses}

The station of Mbour is under the influence of a typical Sahelian climatic cycle composed of two contrasted dry and wet seasons observed around the Equator, which originate from the closeness of the Intertropical Convergence Zone (ITCZ), bringing moist air masses and heavy precipitation. Kaly et al. (2015), based on 5 years of observations (2006-2010) at Mbour, defined the dry season as the period during which no precipitation occurs from November to April and the wet season from May to October, where significant precipitation is measured, with a transition during April-May. In the work of Mortier et al. (2016), who analyzed data from 2006 to 2012 at Mbour, the seasons are defined based on RH levels: from December to March-April $(\mathrm{RH}<40 \%)$ for the dry season and from June to September $(\mathrm{RH} \sim 80 \%)$ for the wet season. They also observed different wind patterns at the ground level, i.e., trade winds coming mostly from the northeast during the dry season, whereas the wet season was characterized by winds from the west. During the AMMA field campaign in the Sahelian belt, Haywood et al. (2008) defined the period from May to June as the monsoon onset. Finally, Slingo et al. (2008) also mentioned large interannual variability in the seasonal progression of moisture, with no clearly reproducible pattern from year to year in Niamey, Niger.

Therefore we based the definition of the dry and wet seasons in this work on the observed weather parameters during the field campaign. Since absolutely no precipitation was ob- served during the whole period, but differences in $\mathrm{RH}$ levels - though not as pronounced as reported by Mortier et al. (2016) - and wind patterns were clearly visible (Fig. 2a), we considered March $(\mathrm{RH}=49 \%)$ and April $(68 \%)$ to belong to the dry season, and May (82\%) and June (84\%) to the transition period.

During IOP-1 two main prevailing directions were found (Fig. 2a). The first one corresponds to an oceanic influence characterized by surface winds coming from west-southwest to northwest $\left(210-300^{\circ}\right)$ with a total frequency of $56 \%$ and wind speeds between 2 and $4 \mathrm{~m} \mathrm{~s}^{-1}$. The second predominant direction is observed for winds originating from northwest to northeast $\left(300\right.$ to $\left.60^{\circ}\right)$ with a total frequency of around $42 \%$ and similar wind speeds $\left(2-4 \mathrm{~m} \mathrm{~s}^{-1}\right)$. The remaining wind sector $\left(60-210^{\circ}\right)$ is a negligible fraction (2\%) (Fig. 2a). The maximum wind speed, $6.8 \mathrm{~m} \mathrm{~s}^{-1}$, was measured on 21 June 2015 , with values above $6 \mathrm{~m} \mathrm{~s}^{-1}$ recorded between 02:00 and 06:00 LT. and associated with SW direction. The period from the end of March to April was dominated by winds coming from the northwest to northeast $(\sim 62 \%)$ with some occurrences $(\sim 33 \%)$ of western winds during the sea breezes, while from May to June winds were mainly originating from the west $(72 \%)$.

Our measurements during IOP-1 are generally consistent with monthly average frequencies of Mbour surface wind directions reported by Kaly et al. (2015) between 2006 and 2010. Indeed, their climatology has shown that spring months are generally influenced by winds coming predominantly from two main sectors, north to east $\left(0-90^{\circ}\right.$, prevailing in March-April) and northwest to southwest (315-225 dominant in May-June).

Each sampling day of IOP-1 was classified according to the locally measured surface wind directions. Three categories of days were indeed identified: (i) days exclusively under northern trade wind influences, i.e., within $\pm 45^{\circ}$ of the north $\left(0^{\circ}\right)$ direction, associated with continental influence, have been defined as "continental" (Fig. 2b); (ii) days dominated by westerly winds corresponding to oceanic air masses have been classified as "marine" days (Fig. 2b); (iii) an intermediate category called "sea breeze" days has been observed during which measurements show winds coming from the northeast before 14:00 LT, then shifting from the north to west directions between 14:00 and 19:00 LT, and returning to the northwest in the evening (Fig. 2b). This phenomenon has been previously observed in Mbour during the AMMA campaigns as reported by Derimian et al. (2008), Léon et al. (2009) and Deboudt et al. (2012). In summary, among the 91 days of IOP-1, 19\% were classified as continental days, $32 \%$ as sea breeze days and $49 \%$ as marine days. The frequent occurrence of marine days can be explained by the transition from dry to wet season from April to June in the Sahelian region (Redelsperger et al., 2006; Slingo et al., 2008). 

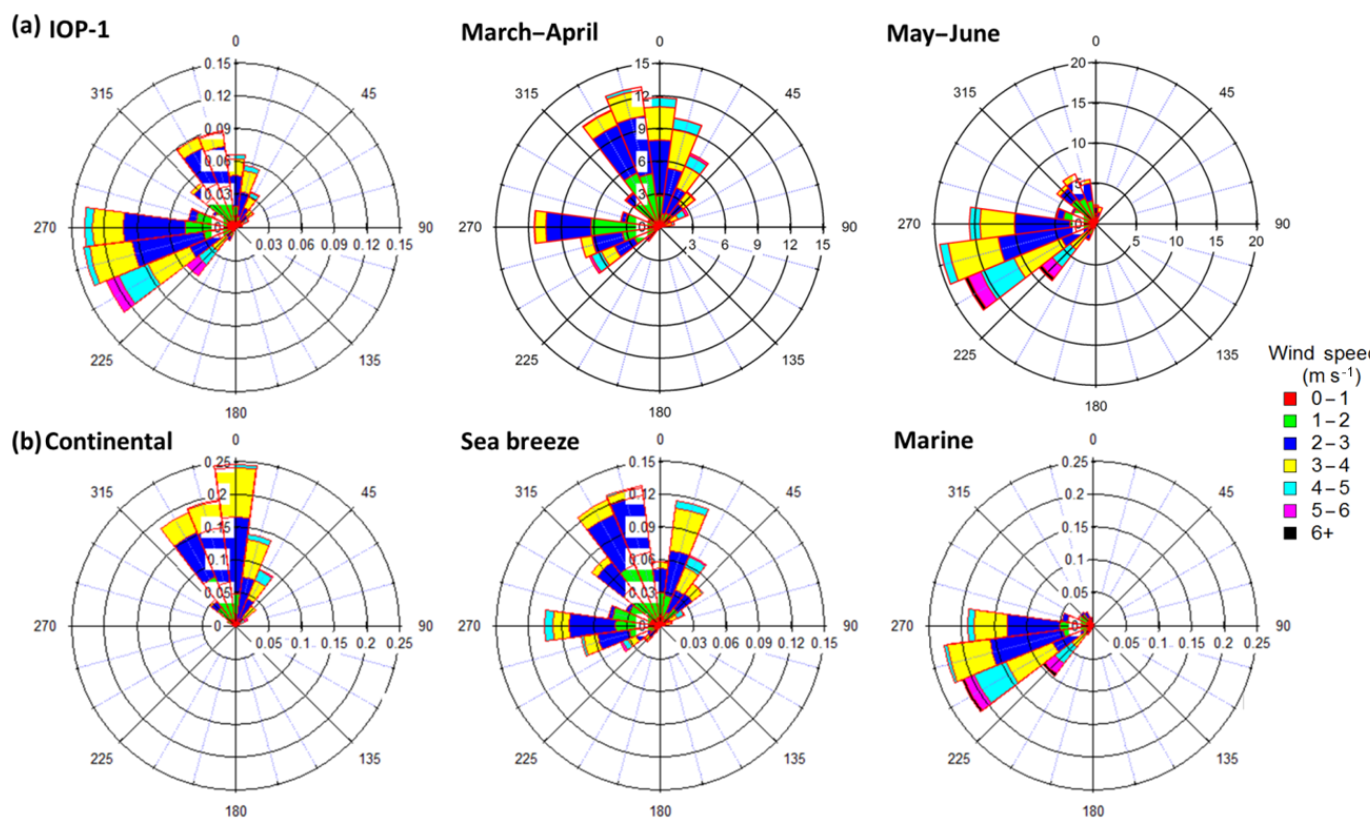

Figure 2. Rose plots of wind direction divided into $15^{\circ}$ sectors and averaged over $30 \mathrm{~min}$ (ACSM time step) with wind frequencies as radius (in \%) and colored by wind speed intervals measured in Mbour for (a) the whole dataset and dry and wet months and (b) days classified as continental $(n=17)$, sea breeze $(n=29)$ and marine $(n=45)$.

\subsubsection{Interpretation of absorption measurements}

Mbour being largely under the influence of mineral dust, a possible overestimation of the amount of $\mathrm{BC}$ derived from absorption coefficients measured by the Aethalometer (due to DD absorbing properties at shorter wavelengths) has to be considered (Bond and Bergstrom, 2006). These interferences may be enhanced during the dry season by internal mixture of $\mathrm{BB}$ and $\mathrm{DD}$, as encountered and evidenced during AMMA by Deboudt et al. (2010) at the surface and by Hand et al. (2010) and Paris et al. (2010) at higher altitudes. Consequently, BC absorption coefficients have been recalculated following the method developed by Fialho et al. $(2005,2006,2014)$ in order to obtain BC concentrations unbiased by DD influence. It consists of a deconvolution of the wavelength-dependent aerosol absorption coefficient over time, $\sigma_{\text {aer }}(\lambda, t)$, into two terms that take into account $\mathrm{DD}$ and $\mathrm{BC}$ contributions, through the following equations.

$\sigma_{\text {aer }}(\lambda, t)=\sigma_{\mathrm{BC}}(\lambda, t)+\sigma_{\mathrm{DD}}(\lambda, t)$,

where $\sigma_{\mathrm{BC}}(\lambda, t)$ and $\sigma_{\mathrm{DD}}(\lambda, t)$ are $\mathrm{BC}$ and DD absorption coefficients, respectively, which can be expressed as a function of the species concentrations $\left\langle C_{i}(t)\right.$ :

$\sigma_{\mathrm{BC}}(\lambda, t)=K_{\mathrm{BC}} \lambda^{\alpha}\left\langle C_{\mathrm{BC}}(t)\right\rangle$,

$\sigma_{\mathrm{DD}}(\lambda, t)=\mathrm{K}_{\mathrm{DD}} \lambda^{\beta}\left\langle C_{\mathrm{DD}}(t)\right\rangle$.

$K_{\mathrm{BC}}$ and $K_{\mathrm{DD}}$ are empirical constants dependent on instrument characteristics, and $\alpha$ and $\beta$ are BC and DD absorption exponents, respectively. The $\alpha$ and $\beta$ values of -1 and
-4 , respectively, have been determined in the visible range (from 470 to $660 \mathrm{~nm}$ ) by Fialho et al. (2014) with a dataset acquired in the Cape Verde islands, located approximately $500 \mathrm{~km}$ from our sampling site.

Fialho et al. (2006) have replaced dust with iron in order to calculate an iron concentration from dust absorption:

$K_{\mathrm{Fe}}\left\langle C_{\mathrm{Fe}}(t)\right\rangle=K_{\mathrm{DD}}\left\langle C_{\mathrm{DD}}(t)\right\rangle$.

Indeed, DD absorption is known to be mainly influenced by the iron content (Lafon et al., 2006) even if this element presents rather low mass contribution to the mineral dust total mass. As mentioned by Fialho et al. (2014), this method allows the estimation of elemental iron concentrations only in the absence of brown carbon since an absorption Angström exponent of 1 (which correspond to fossil fuel BC) is applied. Therefore, other methods, such as the one proposed by Sandradewi et al. (2008) to deconvolve BC from fossil fuel and biomass burning, cannot be used in our conditions. The $m / z 60$ signal $\left(\mathrm{C}_{2} \mathrm{H}_{4} \mathrm{O}_{2}^{+}\right.$, fragment characteristic of levoglucosan from biomass burning) was mostly absent in the ACSM dataset during IOP-1, representing on average only 0.003 (0.007 and 0.012 for the 95th and 99th percentiles, respectively; see Fig. S9) of the total OM, which is identical to the threshold value of $0.3 \%$ suggested by Cubison et al. (2011) to assess the presence of BB aerosols. This point is discussed further in the source apportionment results, in which we tend to attribute $m / z 60$ emissions to other sources. A few data points (less than $1 \%$ of the dataset), under the influence of other combustion processes from specific local ac- 
tivities that may cause a bias in the deconvolution algorithm, have been excluded to derive Fe concentrations (see further discussion in Sect. III.3.2.2).

Combining Eq. (4) with Eqs. (1, 2 and 3) leads to the following expression:

$\frac{\sigma_{\mathrm{aer}}(\lambda, t)}{\lambda^{\alpha}}=K_{\mathrm{BC}}\left\langle C_{\mathrm{BC}}(t)\right\rangle+K_{\mathrm{Fe}}\left\langle C_{\mathrm{Fe}}(t)\right\rangle \lambda^{(\beta-\alpha)}$.

Equation (5) can be plotted as a linear equation at each time $t$ to determine the intercept at the origin, $a(t)$, and the slope, $b(t) . \mathrm{BC}$ and $\mathrm{Fe}$ concentrations are then derived using $K_{\mathrm{BC}}=14.625 \mu \mathrm{m} \mathrm{m}^{2} \mathrm{~g}^{-1}$ in Eq. (6) and $K_{\mathrm{Fe}}=0.234 \mu \mathrm{m}^{4} \mathrm{~m}^{2} \mathrm{~g}^{-1}$ in Eq. (7), respectively:

$\left\langle C_{\mathrm{BC}}(t)\right\rangle=\frac{a(t)}{K_{\mathrm{BC}}}$,

$\left\langle C_{\mathrm{Fe}}(t)\right\rangle=\frac{b(t)}{K_{\mathrm{Fe}}}$.

In the rest of the paper, when $\mathrm{BC}$ and $\mathrm{Fe}$ concentrations are mentioned, it corresponds to the deconvolved values based on the above-mentioned method.

Applying the propagation for uncertainties approach on the values of $K_{\mathrm{Fe}}(10 \%)$ and the slope $b(39 \%$, calculated using a variability of 0.2 for $\alpha$ and $\beta$ (Fialho et al., 2006)) gives an overall uncertainty of $\sim 40 \%$ for iron concentrations. However the deconvolution algorithm is highly sensitive to the values of the Angström absorption exponents ( $\alpha$ and $\beta$ ), and a more detailed discussion can be found in Supplement S1.

\subsubsection{Positive matrix factorization (PMF)}

The PMF model is a statistical source-receptor model developed by Paatero and Tapper (1994), largely employed in source apportionment of atmospheric pollutants when the source profiles and contributions are not known a priori. In this study, PMF was applied on the ACSM organic and chloride mass spectra by using the multilinear engine (Paatero and Tapper, 1994) and the version 5.3 of the source finder (SoFi) described in Canonaco et al. (2013) and operated with IgorPro 6.37 (Wavemetrics). PMF is based on a bilinear model described by the following equations:

$X=\mathbf{G F}+\mathbf{E}$,

$x_{i j}=\sum_{k=1}^{p}\left(g_{i, k} f_{k, j}\right)+e_{i, j}$,

where $X$, corresponding to model entries, represents the matrix of mass fragment spectra measured, and $\mathbf{G}$ and $\mathbf{F}$ are matrices of a $k$ factor concentration time series and $m / z$ profile, respectively, where $i$ denotes the time step and $j$ the mass fragment. The number of factors $p$ is formerly determined by the user. The residual matrix $\mathbf{E}$, containing the unexplained fraction of the PMF solution, is minimized by iterations of the model using the $Q$ function:

$Q=\sum_{i} \sum_{j}\left(\frac{e_{i j}}{s_{i j}}\right)^{2}$, where $s_{i j}$ represents the measurement uncertainties of fragment $j$ at time $i$. The $Q$ value is then normalized by $Q_{\exp }$, representing the degrees of freedom of the model solution. This normalization is used as an indicator for the solution reliability. Thus a ratio $Q / Q_{\exp }$ equal to 1 means that both variability and uncertainties are totally explained by the model. In case of mixed (known) factors, the solution can be furthermore constrained by imposing reference factor profiles $(F$, from the literature) as inputs. The user can apply those constraints with a certain degree of freedom defined by a scalar $a$ value ranging from 0 (no degree of freedom) up to 1 (totally unconstrained).

\subsubsection{Geographical origins of air masses and chemical species}

Air masses reaching the site were characterized through $48 \mathrm{~h}$ back trajectories (every $3 \mathrm{~h}$ ) retrieved from the computer version of the Hybrid Single-Particle Lagrangian Integrated Trajectory model (HYSPLIT; Draxler and Hess, 1998), for an altitude set at one half of the mixed-layer depth and coupled with the GDAS $\left(1^{\circ}\right)$ meteorological database. Note that sea breeze phenomena, which occur on short timescales and spatial scales, cannot be satisfactorily reproduced by this type of model. However, given the dynamics of sea breezes, only back trajectories arriving on-site at 15:00 LT and eventually at 18:00 LT during sea breeze days $(<8.2 \%)$ could not be representative of the ground dynamic observations. Therefore all the back trajectories available for IOP-1 were kept and could be statistically grouped into clusters according to the variation of the total spatial variance, for the whole period and also by day type.

We also used pollution roses to identify local wind directions leading to high concentrations for each species or PMF factors, but also two additional tools provided by the ZeFir Igor-based package developed by Petit et al. (2017): (i) nonparametric regression (NWR, Henry et al., 2009) plots, which combine smoothed surface concentrations and local wind speed and direction, to discriminate between local and more distant or regional sources; (ii) potential source contribution function (PSCF, Polissar et al., 2001) maps for regional sources, which couple time series of one variable with air mass back trajectories to redistribute the concentrations observed at the site into geographical emission parcels. 


\section{Results and discussion}

\subsection{Chemical characterization and temporal behavior}

\subsubsection{NR PM $\mathrm{PM}_{1}, \mathrm{PM}_{1}$ and $\mathrm{PM}_{10}$ mass concentrations}

As previously mentioned, Senegal is widely influenced by $\mathrm{DD}$ events transported from arid and semiarid regions of Sahara and Sahel. Moreover, Mbour being a coastal site, the influence of SS particles on the measured aerosol mass concentrations may be significant. Thus, the contributions of these two aerosol types, in both the coarse and fine fractions of aerosol, have been investigated. $\mathrm{PM}_{1}$ chemical mass closure was checked for all day types by subtracting from the TEOM-FDMS measurements the mass concentrations of species determined by ACSM (NR $\mathrm{PM}_{1}$ ) and Aethalometer $(\mathrm{BC}+\mathrm{Fe})$; the fraction of unaccounted material therefore corresponded to DD and SS contributions.

Figure 3a shows the mass concentration time series of NR $\mathrm{PM}_{1}$ measured by ACSM, total $\mathrm{PM}_{1}$ by TEOM-FDMS, and $\mathrm{PM}_{10}$ by TEOM during IOP-1. It must be noted that total $\mathrm{PM}_{1}$ data acquired between 28 March and 10 April had to be invalidated due to instrument overheating during a dust storm event when the outside temperature reached $42^{\circ} \mathrm{C}$ and $\mathrm{PM}_{10}$ concentrations exceeded $600 \mu \mathrm{g} \mathrm{m}^{-3}$.

The temporal evolutions of the three aerosol fractions do not show any particular correlations (the highest correlation coefficient is obtained between the $\mathrm{PM}_{1}$ and $\mathrm{PM}_{10}$ mass concentrations with $r=0.39$ for $n=2666)$. The weak correlation $(r=0.26, n=2946)$ between $\mathrm{NR} \mathrm{PM}_{1}$ and $\mathrm{PM}_{1}$ might be explained by the contribution of refractory material (DD and SS) to the total $\mathrm{PM}_{1}$, while the absence of correlation $(r=0.08, n=3424)$ between $\mathrm{NR} \mathrm{PM}_{1}$ and $\mathrm{PM}_{10}$ was expected, as well as the low average contribution $(8 \%)$ of NR $\mathrm{PM}_{1}$ to $\mathrm{PM}_{10}$. Indeed, the coarse fraction of aerosol $\left(\mathrm{PM}_{10}\right)$ at this site is dominated by DD and SS (Flament et al., 2011). NR species represent on average $71 \%$ of the total $\mathrm{PM}_{1}$, which underlines the significant influence of refractory material in the fine fraction of aerosol measured at Mbour. During IOP-1, as shown in Fig. 3b, despite an important variability (values ranging between 4 and $25 \%$ ), submicron particles (both refractory and nonrefractory fractions) represent on average $11 \%$ of the $\mathrm{PM}_{10}$ fraction, whatever the day type. This pattern has already been observed at other sites influenced by Saharan emissions, and consequently under the influence of DD such as Granada (Titos et al., 2015) or Cape Verde (Pio et al., 2014).

Despite similar orders of magnitude between the values of NR $\mathrm{PM}_{1}$ and total $\mathrm{PM}_{1}$, their ratio exhibits different trends depending on day type (Fig. 3c). When comparing $\mathrm{PM}_{1}$ and NR $\mathrm{PM}_{1}$ concentrations for marine days, NR species appeared to account for most of the $\mathrm{PM}_{1}$ fraction over IOP1 (slope: $0.71, r=0.82, n=452$ ), suggesting a minor influence of sea salt in the $\mathrm{PM}_{1}$ fraction. This conclusion is consistent with the analysis of Flament et al. (2011) during the AMMA SOP-0 in Mbour, with a reported $\mathrm{PM}_{2}$ fraction composed of 18 to $77 \%$ of DD and less than $20 \%$ of soluble ions (dominated by $\mathrm{NaCl}$ ). Additionally, for continental and sea breeze scatter plots also reported in Fig. 3c, the discrepancies between NR and total $\mathrm{PM}_{1}$ mass concentrations are higher (slopes of 0.49 and 0.56 , respectively), underlying that continental air masses - predominant during those days carried additional refractory material such as DD in the submicron fraction. The unaccounted fraction was determined as the difference between the gravimetrically measured $\mathrm{PM}_{1}$ mass concentration and the sum of chemical species from ACSM (Org, $\mathrm{NO}_{3}, \mathrm{SO}_{4}, \mathrm{NH}_{4}, \mathrm{Chl}$ ) and Aethalometer (BC, $\mathrm{Fe}$ ) measurements. It corresponded to 27,26 and $16 \%$ of the $\mathrm{PM}_{1}$ mass for continental, sea breeze and marine days, respectively (see Fig. S3). A more significant difference could have been expected for continental compared to other days, but this might be explained by the absence of $\mathrm{PM}_{1}$ mass measurements during the more intense dust events, as mentioned previously. Nevertheless, these results stress the need to apply Fialho et al. (2014) deconvolution in order to separate $\mathrm{DD}$ and $\mathrm{BC}$ absorption contribution.

\subsubsection{Estimation of absorbing compound concentrations in $\mathbf{P M}_{1}$}

$\mathrm{Fe}$ and $\mathrm{BC}$ concentrations obtained after correction led to averaged values of $0.55 \pm 0.85$ and $0.36 \pm 0.37 \mu \mathrm{g} \mathrm{m}^{-3}$, respectively, over the whole IOP-1 dataset. The deconvolution led to an average decrease of $45 \%$ of $\mathrm{BC}$ concentrations (factor of 2.2), which is much higher than the $11 \%$ decrease observed by Doumbia et al. (2012) in Dakar, where local BC sources are predominant. In our study the decrease even reached $83 \%$ under the influence of Saharan dust events and therefore the influence of DD on absorption measurements could never be neglected. As depicted in Fig. 4, BC concentrations hardly exceeded $3 \mu \mathrm{g} \mathrm{m}^{-3}$, except throughout punctual and short-term episodes during which they reached higher values, with a half-hourly average maximum of $3.6 \mu \mathrm{g} \mathrm{m}^{-3}$ reached on 2 April 2015. The higher concentrations can be attributed to local anthropogenic combustion processes as $\mathrm{BC}$ concentrations present a significant correlation $(r=0.79)$ with the ACSM $m / z 57$ tracer of all types of combustion. BC concentrations measured in Mbour are on average much lower than those measured in Dakar during POLCA (Doumbia et al., 2012), where BC yearly average was $10.5 \pm 3.5 \mu \mathrm{g} \mathrm{m}^{-3}$. The lower concentrations measured here can be explained by the differences in sampling site type and population, with the IRD center being located at the outskirts of the city of Mbour (180000-200000 inhabitants) area while the site in Dakar (about 3 million inhabitants within the metropolitan area) was located in an urban area. It can be noted that the range of $\mathrm{BC}$ concentrations $\left(0.01-3.6 \mu \mathrm{g} \mathrm{m}^{-3}\right)$ obtained during IOP-1 in Mbour is within the same order of magnitude as the one reported by Liousse 

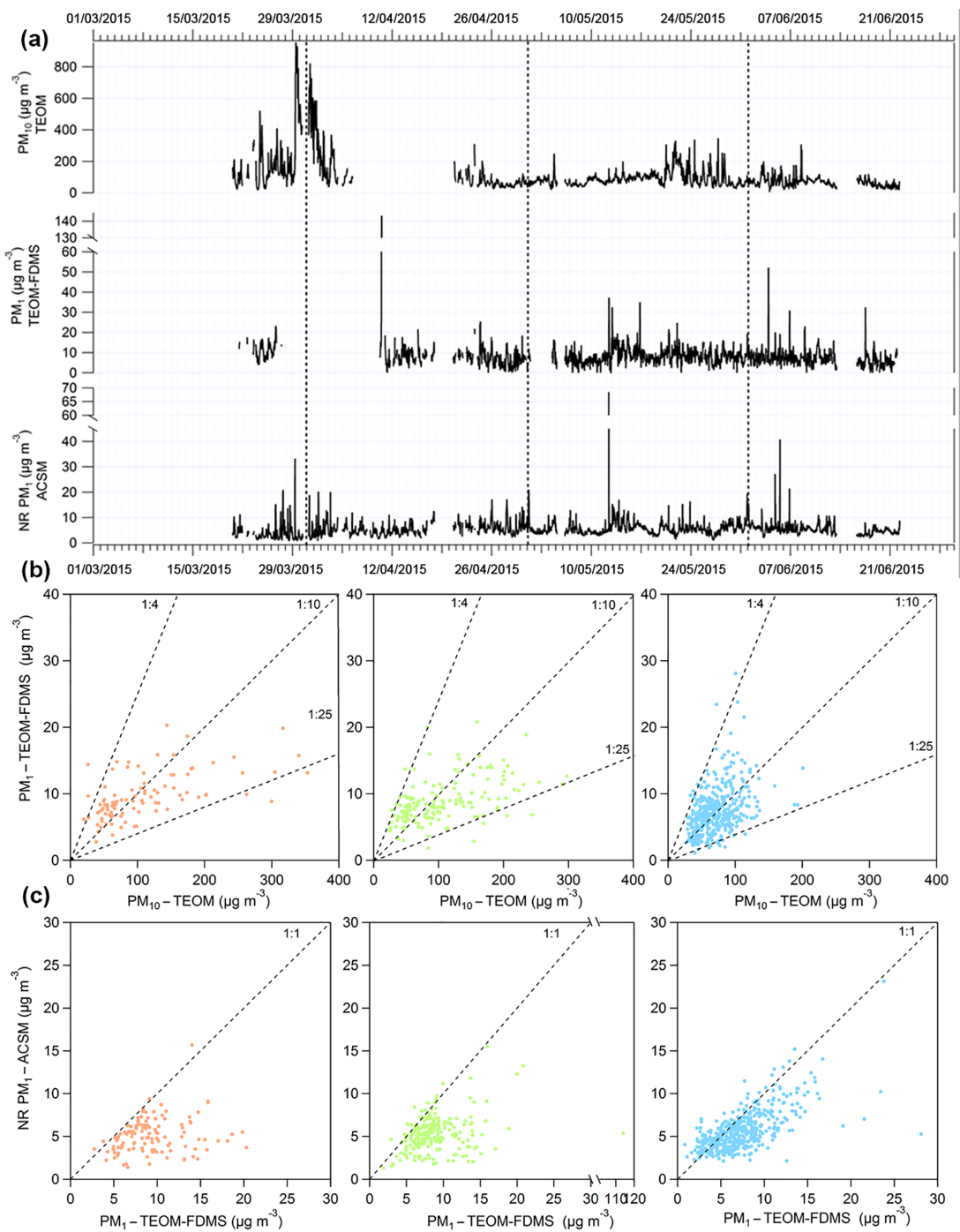

Figure 3. (a) $\mathrm{NR} \mathrm{PM}_{1}$, total $\mathrm{PM}_{1}$ and $\mathrm{PM}_{10}$ time series (30 min averages) measured over IOP-1, (b) $2 \mathrm{~h}$ averaged scatter plots of total $\mathrm{PM}_{1}$ vs. $\mathrm{PM}_{10}$ and (c) $\mathrm{NR} \mathrm{PM}_{1}$ vs. $\mathrm{PM}_{1}$ for (left) continental, (middle) sea breeze and (right) marine days (dotted lines are visual markers representing ratios between the different variables).

et al. (2010) for the rural site of Djougou, Benin, between December 2005 and February $2006\left(0.4-8.2 \mu \mathrm{g} \mathrm{m}^{-3}\right)$.

$\mathrm{Fe}$ concentrations estimated from $\mathrm{PM}_{1}$ absorption measurements are considered as an indicator of DD in the fine fraction. The following comparisons were carried out only on coincident measurements, due to missing data in the $\mathrm{PM}_{1}$ and $\mathrm{PM}_{10}$ datasets, corresponding to lower average concentrations of $\mathrm{Fe}\left(0.39\right.$ and $0.53 \mu \mathrm{g} \mathrm{m}^{-3}$ for the $\mathrm{PM}_{1}$ and $\mathrm{PM}_{10}$ data comparison, respectively). Although weak correlations were found between $\mathrm{Fe}$ and total $\mathrm{PM}_{1}$ concentrations $(r=0.55)$ and unaccounted $\mathrm{PM}_{1}(r=0.47)$, Fe concentrations showed higher correlations with $\mathrm{PM}_{10}(r=0.70$; see Fig. 4). This could be explained by the lack of $\mathrm{PM}_{1}$ mass concentration measurements during intense dust events, as well as DD domination in the coarse fraction, while the fine fraction is mainly driven by $\mathrm{NR}$ and $\mathrm{BC}$ species during most of the IOP-1 (Fig. 3c). As depicted in Fig. 4, most of the low iron concentrations were related to days under marine influence, while the highest Fe concentrations $\left(>8.0 \mu \mathrm{g} \mathrm{m}^{-3}\right)$ are generally associated with continental and sea breeze days. These maxima also coincide with $\mathrm{PM}_{10}$ highest concentrations $\left(>400 \mu \mathrm{g} \mathrm{m}^{-3}\right)$ and confirm iron as a constituent of mineral dust emitted by the Saharan and Sahel regions.

From the only study in the literature focusing on iron concentrations in the submicron fraction in western Africa (Val et al., 2013), we could infer an elemental iron contribution of $7.8 \%$ to $\mathrm{PM}_{1}$ dust, in Dakar, in the absence of dust events. Other studies focused on dust gave the iron contribution for size fractions higher than $\mathrm{PM}_{1}$; thus no straightforward comparisons can be made with our average ratios of Fe / $D_{P_{P M}}$ $(20,23,21$ and $16 \%$ for IOP-1, continental, sea breeze and marine days, respectively). It can nevertheless be interesting 

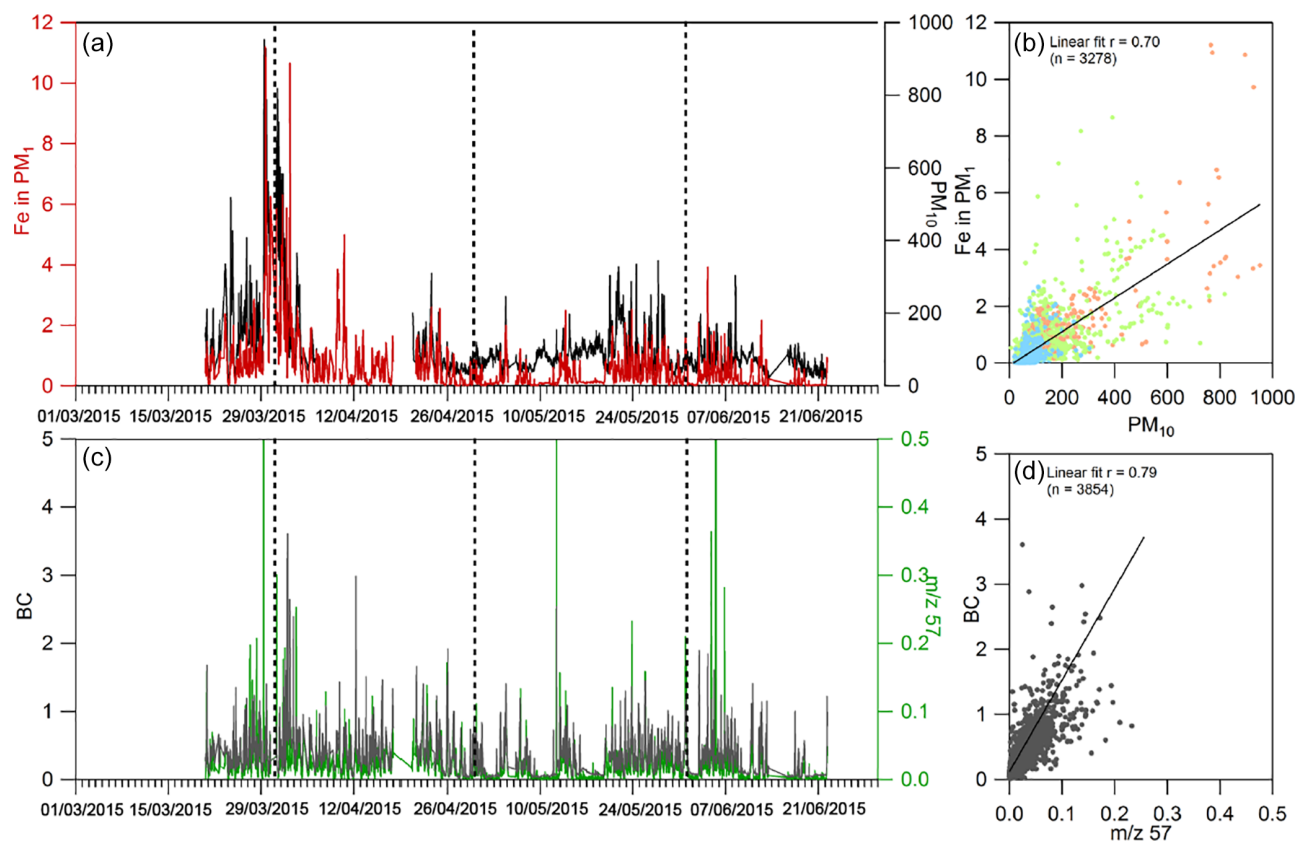

Figure 4. Time series of $\mathrm{Fe}$ and $\mathrm{PM}_{10}$ concentrations (in $\mu \mathrm{g} \mathrm{m}^{-3}$ ) and $\mathrm{BC}$ concentration (in $\mu \mathrm{g} \mathrm{m}^{-3}$ ) and $m / z 57$ (ng m ${ }^{-3}$ ), $30 \mathrm{~min}$ average. (b, d) Corresponding scatter plots and their respective linear fits with Fe and $\mathrm{PM}_{10}$ data colored in red for continental, green for sea breeze and blue for marine days with $\mathrm{BC}$ and $\mathrm{m} / z$ 57 in grey dots.

to have in mind values retrieved within the same region, as it is known that iron oxides mainly belong to the finest fraction (Journet et al., 2014; Kandler et al., 2009) and therefore the elemental iron contribution should be lower for larger sizes, which is consistent with values reported in Table S2.2.

\subsection{3 $\mathrm{PM}_{1}$ average chemical composition}

Table 1 reports ACSM measurements performed at Mbour between 20 March and 22 June 2015, as well as other field campaigns carried out worldwide. This study shows an aver-

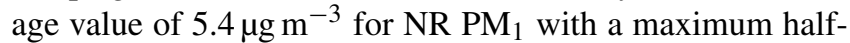
hourly average of $68.3 \mu \mathrm{g} \mathrm{m}^{-3}$. The total $\mathrm{PM}_{1}$ mean concentration (including BC and $\mathrm{Fe}$ ) is $8.2 \mu \mathrm{g} \mathrm{m}^{-3}$ (maximum halfhourly average: $143 \mathrm{\mu g} \mathrm{m}^{-3}$ ), a value which is about 10 times lower than the $\mathrm{PM}_{10}$ mean concentration of $103.5 \mu \mathrm{g} \mathrm{m}{ }^{-3}$ over the same period. This $\mathrm{PM}_{10}$ average is consistent with the range of monthly averages reported by Kaly et al. (2015) at Mbour for the March-June period of 2006-2010 (between 63 and $126 \mu \mathrm{g} \mathrm{m}^{-3}$ ). When compared to similar studies conducted around the world, Mbour clearly appears much less polluted than megacities such as Beijing (Sun et al., 2012) or the Paris area during winter (Petit et al., 2014). The mean NR PM $\mathrm{PM}_{1}$ measured at Mbour is close to those for Welgegund, South Africa (the only other value reported in Africa; Tiitta et al., 2014), continental background sites such as Montsec, Spain (Ripoll et al., 2015), or Paris during summer with an average of $4.5 \mu \mathrm{g} \mathrm{m}^{-3}$ (Petit et al., 2015).
The average $\mathrm{NR} \mathrm{PM}_{1}$ chemical composition measured in Mbour was composed of $\mathrm{OM}(39 \%), \mathrm{SO}_{4}(35 \%), \mathrm{NH}_{4}$ $(15 \%) \mathrm{NO}_{3}(9 \%)$ and $\mathrm{Chl}(\sim 1 \%)$, which is again rather similar to what was observed in South Africa by Tiitta et al. (2014). Indeed, the $\mathrm{OM}$ and $\mathrm{SO}_{4}$ predominance has been also observed in the majority of cities where ACSM (see Table 1) and AMS (Zhang et al., 2007) campaigns were implemented. Nonetheless, during winter, some European sites such as Paris (Petit et al., 2015), Cabauw (Schlag et al., 2016) or Zurich (Lanz et al., 2010) present a fine fraction mainly dominated by nitrate and organic species. In our case these differences could be explained both by the semivolatile nature of $\mathrm{NH}_{4} \mathrm{NO}_{3}$ combined with the limited use of fertilizers that prevent $\mathrm{NH}_{3}$ emissions and ammonium nitrate formation, and more sources of non-SS $\mathrm{SO}_{4}$ such as marine dimethyl sulfide oxidation processes. The first point can be assessed by emission inventories that provide annual $\mathrm{NH}_{3}$ emissions (in 2010) of $53 \mathrm{kT}$ in Senegal compared to $870 \mathrm{kT}$ in France and $204 \mathrm{kT}$ in the Netherlands (ECJRC/PBL, 2011). Non-SS SO 4 comes from secondary origin and has been investigated in $\mathrm{PM}_{10}$ at the Cape Verde Atmospheric Observatory (Fomba et al., 2014). This study showed increased concentrations of non-SS $\mathrm{SO}_{4}$ during dust events, linked to the oxidation of anthropogenic $\mathrm{SO}_{2}$ transported by continental air masses. They also evidenced a seasonal variability of non-SS $\mathrm{SO}_{4}$ for marine air masses, increasing during summer, which was attributed to increased photochemistry and changes in the emission of dimethyl sulfide due to higher biological activities in the ocean. This activity can be 
Table 1. Averaged NR $\mathrm{PM}_{1}$ concentrations (in $\mu \mathrm{g} \mathrm{m} \mathrm{m}^{-3}$ ) - with maximum in parentheses when available - and respective contributions of NR compounds for this study compared to other ACSM campaigns from different locations.

\begin{tabular}{|c|c|c|c|c|c|c|c|c|c|}
\hline \multirow{2}{*}{$\begin{array}{l}\text { NR } \mathrm{PM}_{1} \\
\text { avg. }\left(\mu \mathrm{g} \mathrm{m}^{-3}\right)\end{array}$} & \multicolumn{5}{|c|}{ Relative contributions (\%) } & \multirow[t]{2}{*}{ Period } & \multirow[t]{2}{*}{ Location } & \multirow[t]{2}{*}{ Type of site } & \multirow[t]{2}{*}{ Reference } \\
\hline & OM & $\mathrm{SO}_{4}$ & $\mathrm{NO}_{3}$ & $\mathrm{NH}_{4}$ & Chl & & & & \\
\hline 50.0 & 40 & 18 & 25 & 16 & $<1$ & Jun-Aug 2011 & Beijing (China) & Urban & Sun et al. (2012) \\
\hline 25.9 & 58 & 23 & 7 & 11 & $<1$ & Sep-Dec 2015 & Hong Kong (China) & Urban & Sun et al. (2016) \\
\hline $15.7(80)$ & $\sim 44$ & $\sim 6$ & $\sim 38$ & $\sim 11$ & $\sim 1$ & Jan-Mar 2012 & Paris (France) & Suburban & Petit et al. (2014) \\
\hline 15.3 & 72 & 15 & 6 & 8 & $<1$ & Summer-Fall 2011 & Atlanta (USA) & Urban & Budisulistiorini et al. (2014) \\
\hline 14.2 & 58 & 12 & 21 & 8 & 1 & Mar 2013-Mar 2014 & Ispra (Italy) & Rural background & Bressi et al. (2016) \\
\hline $10.8(\sim 75)$ & 45 & 30 & 11 & 13 & 1 & Sep-Oct 2013 & Menyuan, Tibetan Plateau (China) & Rural & Du et al. (2015) \\
\hline 9 & 31 & 12 & 41 & 14 & 2 & Jul 2012-Jun 2013 & Cabauw (the Netherlands) & Rural & Schlag et al. (2016) \\
\hline $7.5(89)$ & 48 & 32 & 7 & 13 & $<1$ & Sep 2010-Aug 2011 & Welgegund (South Africa) & Rural & Tiitta et al. (2014) \\
\hline 7.2 & 52 & 29 & 7 & 12 & $<1$ & Jul-Sept 2010 & New York (USA) & Urban & $\mathrm{Ng}$ et al. (2011a) \\
\hline 7.0 & 57 & 12 & 21 & 9 & $<1$ & Nov 2010-Jun 2012 & Southern Great Plains (USA) & Rural & Parworth et al. (2015) \\
\hline$\sim 7.0$ & 54 & 19 & 11 & 11 & $<5$ & Jun 2012-Jul 2013 & Montseny (Spain) & Rural & Minguillón et al. (2015) \\
\hline $5.4(68.3)$ & 39 & 35 & 9 & 15 & $<1$ & Mar-Jun 2015 & Mbour (Senegal) & Suburban & This study \\
\hline 4.9 & 53 & 25 & 7 & 12 & $<1$ & Jul 2011-Apr 2012 & Montsec (Spain) & Rural & Ripoll et al. (2015) \\
\hline $0.3(9.6)$ & 43 & 30 & 7 & 17 & / & Oct 2012-Oct. 2013 & Jungfraujoch (Switzerland) & Rural & Fröhlich et al. (2015) \\
\hline
\end{tabular}

traced back using satellite data from Aqua MODIS, in particular the algae concentrations along the Senegalese coast (Ocean biology processing group, 2003).

Figure 5 represents the average contributions of $\mathrm{NR} \mathrm{PM}_{1}$ species, $\mathrm{BC}$ and $\mathrm{Fe}$ in $\mathrm{PM}_{1}$ over the entire IOP-1 and more specifically for continental, sea breeze and marine days. Total $\mathrm{PM}_{1}$ pie charts, including unaccounted-for aerosol species obtained by chemical mass closure, have been reported in the supplementary material section (Fig. S3). Figure 5 shows that although an almost equal proportion of organic and sulfate species ( 31 and $32 \%$ respectively) was measured on average over the whole IOP-1, strong differences regarding day types can be highlighted: continental and sea breeze days present similar averaged compositions, with a major contribution of OM (36-40\%) followed by $\mathrm{SO}_{4}$ with $21-24 \%$. Similarities between the two profiles are probably due to a longer influence of northern wind compared to western ones during sea breeze days. However, for marine days the dominant fraction is sulfate (40\%) while the OM-averaged contribution decreased to $25 \%$. These changes could be explained by (i) oceanic air masses known to carry higher amount of sulfate species from the oxidation of dimethyl sulfide and organosulfur gases (Charlson et al., 1987; Fitzgerald, 1991) and (ii) long-range transport of polluted air masses from the continent, carried back to Mbour through oceanic air masses. $\mathrm{BC}$ and $\mathrm{Fe}$ from anthropogenic and continental origins, respectively, are also less abundant during marine days compared to continental and sea breeze days, with fractions decreasing from 7 to 3 and from $14-16$ to $3 \%$ (for anthropogenic and continental origins, respectively).

Comparable dynamics was already observed at Mbour during AMMA SOP-0. For instance, Haywood et al. (2008) highlighted that $\mathrm{BB}$ aerosols carried at high altitude $(\sim 3 \mathrm{~km})$ from the African continent to the Atlantic Ocean were then driven back through southwesterly winds. Similar contributions have been observed in Welgegund (Tiitta et al., 2014), where $\mathrm{PM}_{1}$ measured during the dry season was dominated
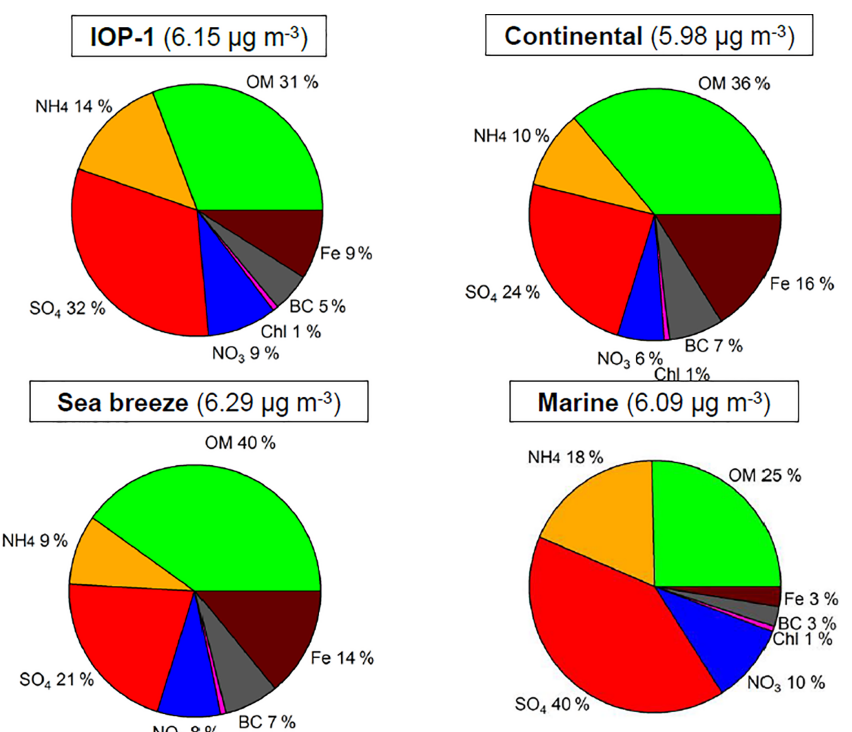

Figure 5. Averaged contributions of NR PM 1 , BC and Fe for IOP-1 $(n=3771)$, continental $(n=307)$, sea breeze $(n=799)$ and marine days $(n=1843)$, with average total concentration in micrograms per cubic meter $\left(\mu \mathrm{g} \mathrm{m}^{-3}\right)$ in parentheses.

by $\mathrm{OM}(57 \%)$, followed by $\mathrm{SO}_{4}(16 \%)$ and $\mathrm{BC}(10 \%)$, and the wet season marked by high contributions of $\mathrm{SO}_{4}(42 \%)$ and lower contributions of $\mathrm{OM}$ and $\mathrm{BC}$ (35 and $4 \%$, respectively). In Mbour, we obtained a significant correlation $(r=0.74$, Fig. S11) between the OM and BC time series and an average $\mathrm{BC} / \mathrm{OM}$ ratio of 0.15 , whatever the day type, suggesting similar emission sources and therefore pointing to continental origins either directly linked to combustion processes, as both species displayed a more important contribution during continental and sea breeze days, or due to the mixing of anthropogenic emissions with biogenic precursors or secondary organic aerosols (SOA). 
Aerosol acidity can be considered as an indicator of the age of particles as they will get neutralized during their stay in the atmosphere. In order to estimate the degree of neutralization of ACSM inorganic species, $\mathrm{NH}_{4}$ measured concentrations (as $\mathrm{NH}_{2}^{+}, \mathrm{NH}_{3}^{+}$and $\mathrm{NH}_{4}^{+}$ions) are compared to predicted ones, which are equal to the amount of $\mathrm{NH}_{4}$ required to fully neutralize sulfate, nitrate and chloride anions according to the following equation (Zhang et al., 2007):

$$
\begin{aligned}
\mathrm{NH}_{4, \text { pred }} & =\mathrm{M}\left(\mathrm{NH}_{4}\right) \\
& \times\left(2 \times \frac{\mathrm{SO}_{4}^{2-}}{\mathrm{M}\left(\mathrm{SO}_{4}^{2-}\right)}+\frac{\mathrm{NO}_{3}^{-}}{\mathrm{M}\left(\mathrm{NO}_{3}^{-}\right)}+\frac{\mathrm{Cl}^{-}}{\mathrm{M}\left(\mathrm{Cl}^{-}\right)}\right),
\end{aligned}
$$

with $\mathrm{SO}_{4}^{2-}, \mathrm{NO}_{3}^{-}$and $\mathrm{Cl}^{-}$the mass concentrations $\left(\mu \mathrm{g} \mathrm{m}^{-3}\right)$ of inorganic species $\mu \mathrm{g} \mathrm{m}^{-3}$ and $\mathrm{M}(X)$ their molecular weights $\left(\mathrm{NH}_{4}: 18 ; \mathrm{SO}_{4}: 96 ; \mathrm{NO}_{3}: 62 ;\right.$ and $\left.\mathrm{Cl}: 35.5 \mathrm{~g} \mathrm{~mol}^{-1}\right)$.

The slope obtained between measured and predicted $\mathrm{NH}_{4}$ (1.02, $r=0.92$; see Fig. S4a) underlined that most of the inorganic species are neutralized over IOP-1, and additionally that there is no strong bias in the calibration values used for ACSM measurements. Nonetheless, a few points digress from the 1:1 line, indicating partially neutralized species (as mentioned above). On the one hand, points significantly above the $1: 1$ ratio suggest the presence of $\mathrm{NH}_{4}$ under other forms than $\left(\mathrm{NH}_{4}\right)_{2} \mathrm{SO}_{4}, \mathrm{NH}_{4} \mathrm{NO}_{3}$ and $\mathrm{NH}_{4} \mathrm{Cl}$. As these points also correspond to higher levels of $\mathrm{OM}, \mathrm{BC}$ and chloride (circled in red in Fig. S4c), they might be related to nitrogen-containing species associated with combustion processes at low RH ( $<50 \%$; Fig. S4a and b), where chlorine could come from the combustion of sea salt and/or chlorinecontaining materials such as plastics. On the other hand, $23 \%$ of the data is associated with a $\mathrm{NH}_{4}$, meas $/ \mathrm{NH}_{4}$,predict ratio less than 0.75 and corresponds to points under the $1: 1$ line in Fig. S4a. For such points, the amount of $\mathrm{NH}_{4}$ predicted is overestimated in comparison to the amount measured on-site, and considering that $\mathrm{NH}_{4}$ will preferentially react with $\mathrm{SO}_{4}$, other anions such as $\mathrm{NO}_{3}$ and $\mathrm{Chl}$ are partially under chemical states other than ammonium nitrate and chloride. As mentioned previously and developed in Sect. 3.2, this can be explained by chloride species emitted by local combustion processes but also by $\mathrm{HNO}_{3}$ adsorption on dust, as already reported in the literature (Fairlie et al., 2010; Savoie et al., 1989). This is consistent with ratio values less than 0.75 , which are mainly observed while the site is under dust influence (Fig. S4b). Nevertheless these periods also correspond to low levels of inorganic species in $\mathrm{PM}_{1}$.

\subsubsection{Variations of $\mathrm{PM}_{1}$ chemical species}

Figure 6 displays the 30 min temporal variability of NR PM species during IOP-1. At such a timestamp a total of 13 pollution events - characterized by $\mathrm{NR} \mathrm{PM}_{1}$ concentrations exceeding a threshold value of $15 \mu \mathrm{g} \mathrm{m}^{-3}$, corresponding to 3 times the average - were detected. In terms of chemical composition, the highest average - over the whole IOP-1 - concentrations were obtained for $\mathrm{OM}$ and $\mathrm{SO}_{4}$ with respective values of 2.12 and $1.85 \mu \mathrm{g} \mathrm{m}^{-3}(n=3931)$. Moreover, OM concentrations could present a high variability over short periods, such as on 12 May 2015 when OM jumped from 0.9 to $61.7 \mu \mathrm{g} \mathrm{m}^{-3}$ over an interval of $30 \mathrm{~min}$, while the sum of other $\mathrm{NR} \mathrm{PM}_{1}$ species remained below $10 \mu \mathrm{g} \mathrm{m}^{-3}$.

$\mathrm{OM}$ and $\mathrm{SO}_{4}$ daily fractions exhibit opposite trends, with periods dominated by OM $(>30 \%)$ at the beginning of IOP1 and from 20 May to 8 June 2015, corresponding to days under continental or sea breeze influences. OM concentrations encountered during these periods are generally related to punctual intense episodes, suggesting an influence linked to emissions by rather local anthropogenic activities rather than long-range transport sources. The periods from 25 April to 21 May and after 9 June 2015, associated with oceanic air masses, are dominated by $\mathrm{SO}_{4}(>30 \%)$, with generally more moderate concentrations and less intense peaks, except for 13 May 2015, with $\mathrm{NR} \mathrm{PM}_{1}$ reaching its maximum at $68 \mu \mathrm{g} \mathrm{m}^{3}$.

The daily profiles of all identified $\mathrm{PM}_{1}$ species and meteorological parameters (wind speed, temperature and wind roses) are presented in Fig. 7 according to day types. Strong similarities can be observed between the continental and sea breeze daily profiles (Fig. 7a-b), both presenting a morning peak around 08:00 LT marked by a distinct rise in OM $\left(>4 \mu \mathrm{g} \mathrm{m}^{-3}\right)$ and $\mathrm{BC}\left(\sim 1 \mu \mathrm{g} \mathrm{m}^{-3}\right)$ concentrations and to a lesser extent in $\mathrm{NH}_{4}$ and chloride concentrations. Continental and sea breeze daily profiles also show a common peak at 20:00 LT, less intense than the morning one, but characterized by an increase in $\mathrm{OM}$ and $\mathrm{BC}$. It can be noticed that this evening peak is less pronounced for continental days $\left(\mathrm{OM} \sim 3.5 \mu \mathrm{g} \mathrm{m}^{-3}\right.$ and $\left.\mathrm{BC} \sim 0.7 \mu \mathrm{g} \mathrm{m}^{-3}\right)$ than for sea breeze days $\left(\mathrm{OM} \sim 4.5 \mu \mathrm{g} \mathrm{m}^{-3}\right.$ and $\left.\mathrm{BC} \sim 0.9 \mu \mathrm{g} \mathrm{m}^{-3}\right)$. As mentioned previously, the $\mathrm{BC} / \mathrm{OM}$ ratio is on average 0.130.14 for sea breeze and continental days (see Fig. S11) but during the morning and evening peaks these ratios can reach a maximum of $\sim 0.25$, meaning that $\mathrm{BC}$ emissions are enhanced during these hours. A specific pattern of continental days is a peak measured at noon for $\mathrm{OM}$ and $\mathrm{BC}$ concentrations (constant $\mathrm{BC} / \mathrm{OM}$ ratio $\sim 0.16$ ), probably combining local emissions and reduced dispersion due to dynamic phenomena, as suggested by the slight wind speed decrease. However, for sea breeze days a peak occurring at 15:00 LT, with an intense increase in $\mathrm{OM}$, a moderate increase in $\mathrm{SO}_{4}$ and almost no variation of $\mathrm{BC}$ (ratio of 0.1 ) coincide with the sea breeze establishment (discernible through wind plots and the slight drop in temperature). BC for continental and sea breeze daily profiles show a maximum intensity of $1.1 \mu \mathrm{g} \mathrm{m}^{-3}$ for the continental morning peak (08:00 LT), a value which is quite consistent with maximal hourly concentrations (up to $4 \mu \mathrm{g} \mathrm{m}^{-3}$ ) measured at 08:00, 16:00 and 20:00 LT in Mbour by Deboudt et al. (2010). These peaks are measured for air masses coming from the continent and correspond to traffic and/or cooking hours. Chloride peaks associated with intense $\mathrm{OM}$ and $\mathrm{BC}$ peaks tend to confirm 


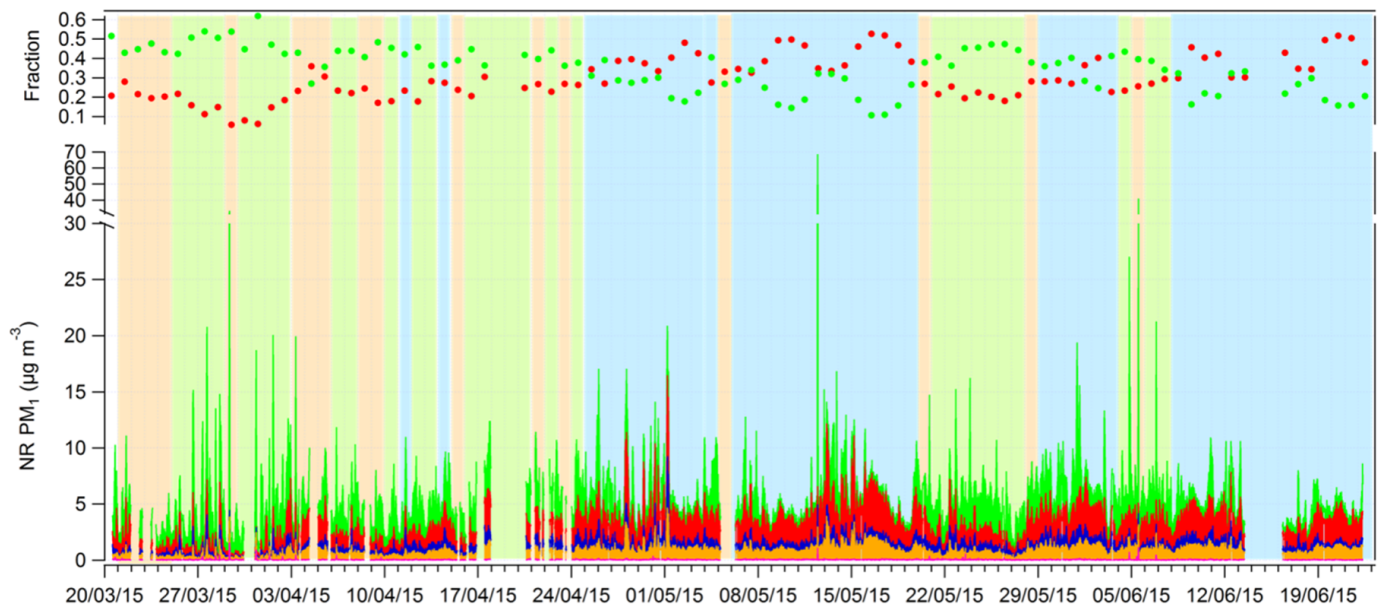

Figure 6. (Bottom) IOP-1 stacked time series of $\mathrm{OM}$ (green), $\mathrm{SO}_{4}$ (red), $\mathrm{NO}_{3}$ (blue), $\mathrm{NH}_{4}$ (orange) and Chl (pink) on an ACSM time step (30 min) and (top) daily averaged fraction of $\mathrm{OM}$ and $\mathrm{SO}_{4}$. Tinted areas correspond to continental days (in light pink), sea breeze days (in light green) and marine days (in light blue).

combustion sources for these species, as previously observed during winter in Beijing by Sun et al. (2013).

The marine averaged daily profiles show a very distinctive pattern, compared to continental and sea breeze days (Fig. 7a), and are characterized by a sharp decrease of OM, $\mathrm{BC}$ and $\mathrm{Fe}$, with nitrate, ammonium and chloride presenting rather constant profiles, while sulfate exhibits a higher and almost constant concentration of $2.4 \mu \mathrm{g} \mathrm{m}^{-3}$. This pattern as well as the sulfate peak associated with the sea breeze tends to confirm the regional transport of sulfate to Mbour through oceanic air masses. It is noticeable that for marine days, OM and $\mathrm{BC}$ profiles reached maximum concentrations of 2.5 and $0.35 \mu \mathrm{g} \mathrm{m}^{-3}$ during the night (between 20:00 and 02:00 LT), in conjunction with low wind speed (Fig. 7d). Thus, this nighttime increase of concentrations measured for marine days might be due to lower dilution of aerosols species from local emissions. The results obtained at Mbour for marine days are in agreement with those reported by Topping et al. (2004) in Korea, with inorganic species such as $\mathrm{SO}_{4}, \mathrm{NO}_{3}$ and $\mathrm{NH}_{4}$ increasing significantly during days under marine influence.

In Fig. 7b, Fe and $\mathrm{BC}$ profiles showed distinctive behaviors depending on day types. As expected, both profiles for marine days are characterized by very low concentrations of both $\mathrm{BC}$ and $\mathrm{Fe}$ in comparison to those measured for sea breeze and continental days. In the latter cases, a major difference can be observed for $\mathrm{Fe}$ concentrations which are almost twice as high as $\mathrm{BC}$ ones. Fe exhibits an additional intense peak around 15:00 LT and concentrations above $1.5 \mu \mathrm{g} \mathrm{m}^{-3}$ from noon to 20:00 LT during continental days, which can be attributed to the intense dust events occurring around the end of March and on 10 April when comparing average and median profiles. These patterns suggest a transport of $\mathrm{BC}$ and $\mathrm{DD}$ (through $\mathrm{Fe}$ ) by continental air masses - from the areas north and northeast of Mbour. Most probably, air masses loaded in DD coming from the Saharan region (Fe continental profile) are then enriched in $\mathrm{BC}$ during their transport above cities. Nonetheless local traffic activities may also be a nonnegligible source of dust through resuspension processes, which would also explain the synchronized peaks of $\mathrm{BC}$ and $\mathrm{Fe}$ observed for continental profiles even when excluding desert dust events.

\subsection{Origins and sources of aerosols}

\subsubsection{Geographical origins of chemical species}

As observed previously, most of the winds reaching Mbour during IOP-1 were associated with the north and west sectors, carrying air masses from the continent and the ocean, respectively, with an averaged wind speed of $2.6 \mathrm{~m} \mathrm{~s}^{-1}$. These results are consistent with the 5-year measurements of wind direction reported by Kaly et al. (2015) in Mbour for the dry season. From back-trajectory analysis (Fig. S5a), three different clusters were encountered during the whole period. The prevailing one (77\% for the whole IOP-1 period; 91,80 and $43 \%$ for continental, sea breeze and marine days, respectively) evidences air masses transported along the western African coast and over Dakar. A second cluster corresponds to air masses purely originating from the ocean (19\% of the total back trajectories) and appeared as two clusters during marine days. A last cluster coming from the Saharan desert contributes only $4 \%$ of the IOP-1 air masses but reaches 9 and $10 \%$ for the continental and sea breeze days, respectively. Figure 8 presents pollution roses obtained combining the time series of the different $\mathrm{PM}_{1}$ components and colocated surface wind direction and wind speed measurements, thus offering a first insight into the geographical origins of chemical species. NWR plots and PSCF maps can be found 

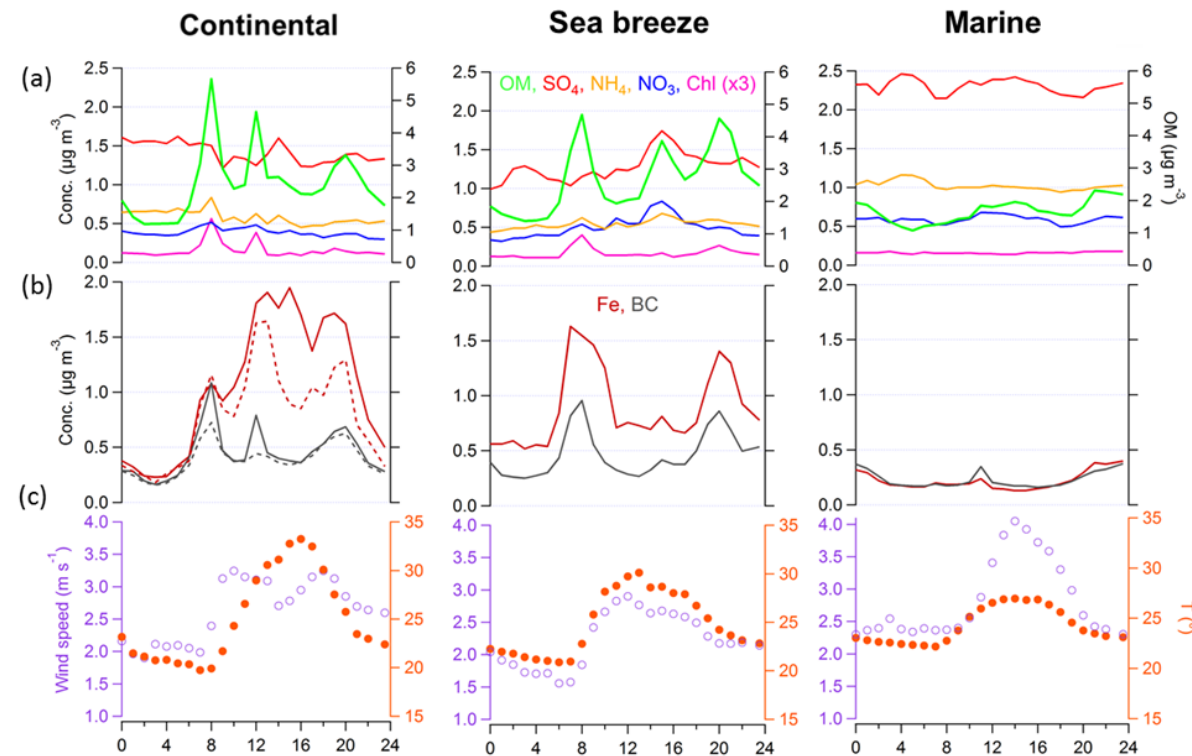

(d)
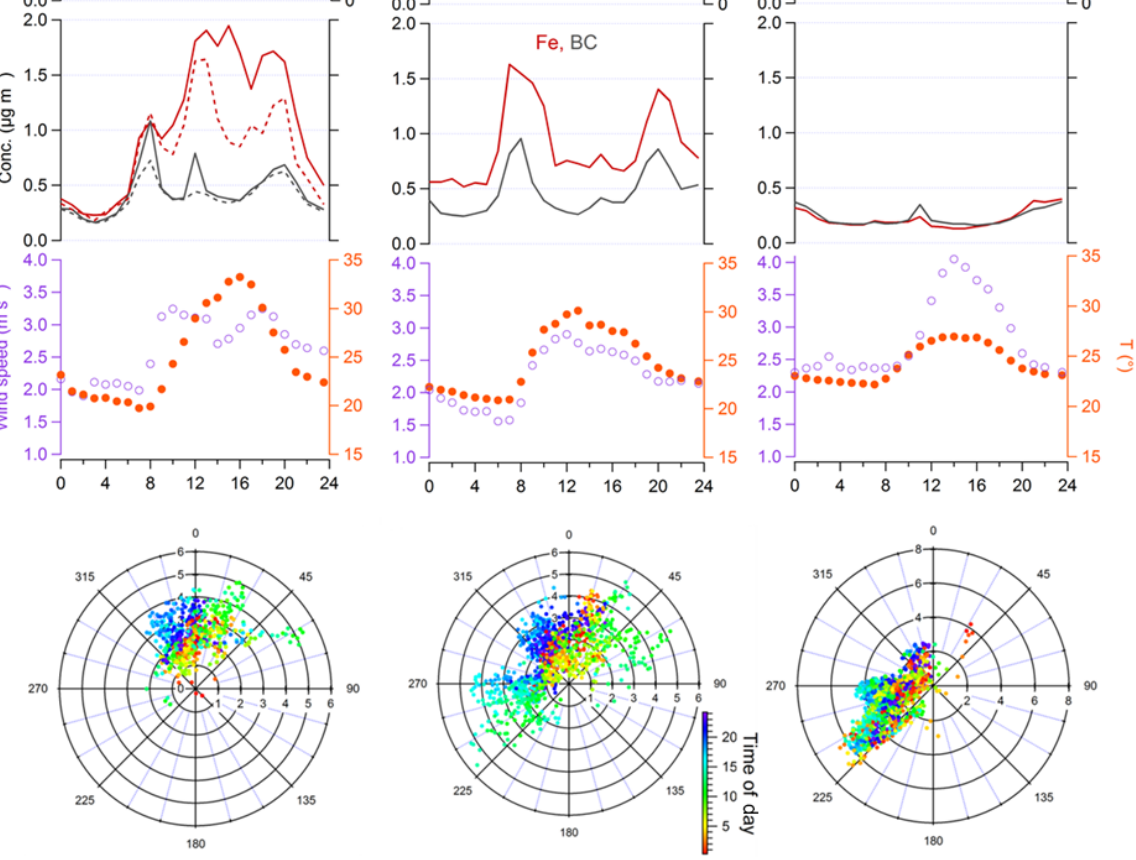

Figure 7. Average daily profiles of (a) $\mathrm{NR} \mathrm{PM}_{1}$, (b) $\mathrm{BC}$ and Fe concentrations, (c) wind speed and temperature for (from left to right) continental (dotted lines: medians), sea breeze and marine days. (d) Associated wind rose plots (radius, wind speed in $\mathrm{m} \mathrm{s}^{-1}$ ) colored by time of day in UTC.
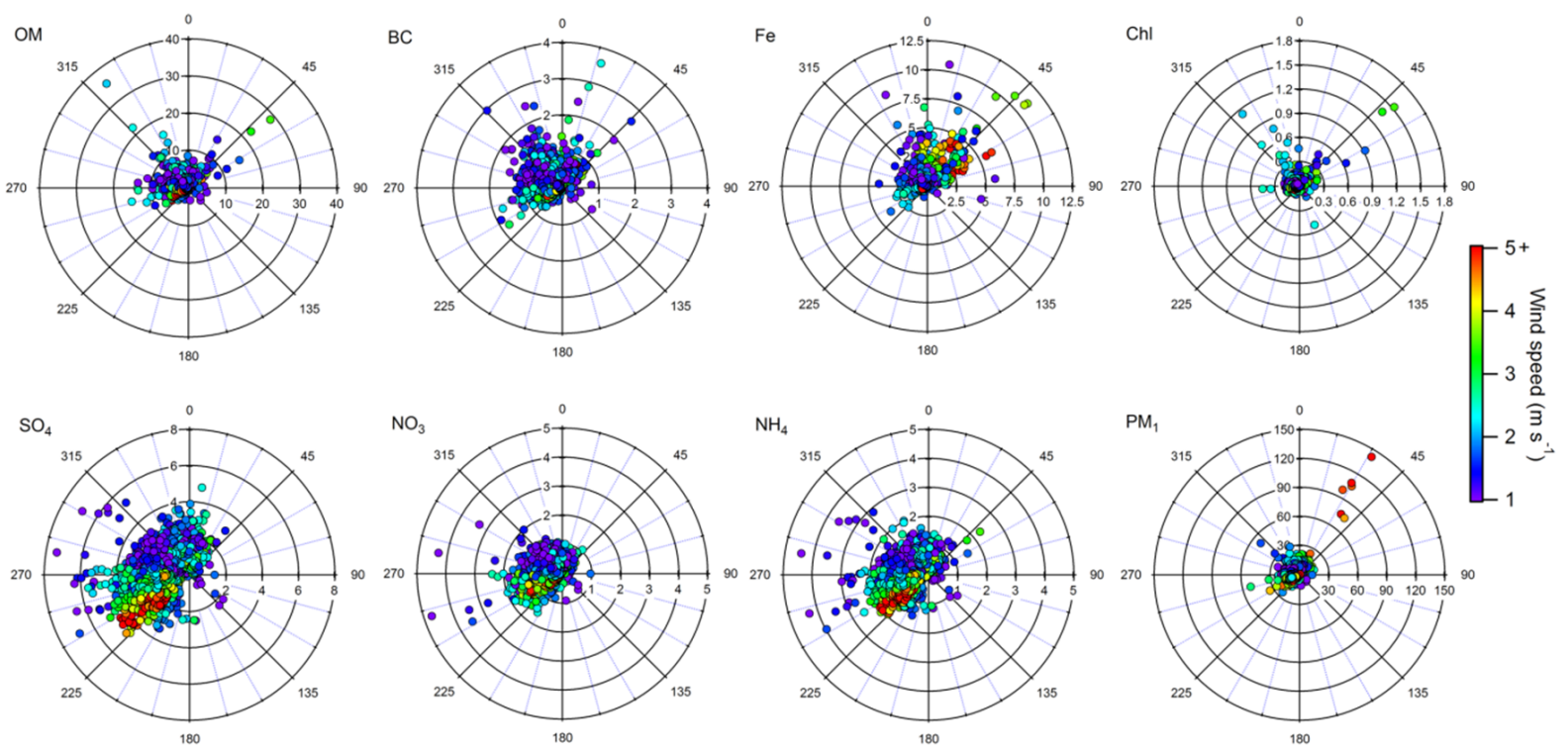

Figure 8. Pollution rose plots of $\mathrm{OM}, \mathrm{BC}, \mathrm{Chl}, \mathrm{Fe}, \mathrm{SO}_{4}, \mathrm{NO}_{3}, \mathrm{NH}_{4}$ and total $\mathrm{PM}_{1}$ for the whole IOP-1, with concentrations $\left(\mu \mathrm{g} \mathrm{m}^{-3}\right)$ as radius and colored by wind speed (measurements less than $1 \mathrm{~m} \mathrm{~s}^{-1}$ in grey). 
in Fig. S5b and S5c, respectively. Similar spatial origins can be observed for several species; in particular, OM, BC and $\mathrm{Chl}$ maximum concentrations are rather associated with northeast winds during morning peaks and northwest winds at the end of the day (Fig. 7), which point to a common origin of the higher concentrations observed for these species, that would be linked to combustion processes due to the presence of $\mathrm{BC}$. $\mathrm{BC}$ and $\mathrm{NO}_{3}$ both exhibit local and regional influences, as suggested by their NWR plots (Fig. S5b). The corresponding PSCF maps (Fig. S5c) indicate that regional background concentrations could come from anthropogenic emissions from Dakar $(\sim 1$ million inhabitants within city limits and $\sim 3$ million in the metropolitan area) and possibly from maritime traffic along the western African coast.

Figure 8 also highlights an oceanic origin for some OM (with moderate intensity), $\mathrm{SO}_{4}$ (as already observed in Fig. 5), $\mathrm{NO}_{3}$ and $\mathrm{NH}_{4}$. There is no clear trend linked to the wind speed (slower along the coast and higher when perpendicular to it), meaning particulate chemical species are transported or formed above the ocean rather than directly emitted by sea spray (Ovadnevaite et al., 2012). Emissions of dimethyl sulfide and organosulfur gases by microorganisms (as mentioned previously) could explain part of the $\mathrm{SO}_{4}$ and OM concentrations observed when the site is under western influence. These species may also be released by anthropogenic activities in distant cities such as Dakar, whose emissions may be carried toward the ocean and brought back to Mbour by western winds. This hypothesis is also supported by back-trajectory analysis (Fig. S5a). A long-term $\mathrm{PM}_{10}$ chemical characterization conducted in Cape Verde by Fomba et al. (2014) has also shown that marine air masses were mostly composed of sulfate $(10 \%$ on average) rather than organic matter $(3.5 \%)$, but the proportion in $\mathrm{PM}_{1}$ is more balanced.

Regarding the iron pollution rose plots and NWR plots reported in Figs. 8 and S5b, maxima are measured when the site is under the influence of northeastern winds. The NWR plot evidences both local emissions possibly linked to traffic resuspension of DD and a regional component, that the Fe PSCF map clearly attributes to the Saharan region. For such directions we also observe maximum values of the total $\mathrm{PM}_{1}$ concentrations $\left(>60 \mu \mathrm{g} \mathrm{m}^{-3}\right.$ ), which correspond to the 10 April 2015, most probably a resuspension event following previous dust storms, as observed on $\mathrm{PM}_{1}$ and Fe concentrations time series (reported respectively in Figs. 3 and 4).

\subsubsection{Source apportionment of OM}

PMF was first applied without constraints on the whole IOP-1 organic database and then separately on continental, sea breeze and marine extracted datasets (see also Supplement S4). For each run, 3 to 10 factors were tested and only solutions with a normalized $Q / Q_{\exp }$ ratio close or less than 1 were taken into account. Mass spectra were compared to reference profiles for identification, and the con- sistency with daily profiles was checked. Without any constraints applied to the model, one or two factors identified as oxygenated organic aerosols (OOA, dominated by the $\mathrm{CO}_{2}^{+}$ fragment at $m / z$ 44) were easily retrieved for all datasets. An unknown factor with peaks at $m / z$ 58, 60, 83 and 91 appears for the whole IOP-1 when the number of factors increases (and is mixed with one of the OOA in the reduced datasets). This factor appeared constantly above 4 factors in the unconstrained runs from 3 to 10 factors (Fig. S6) and was associated with one of the OOA for the continental, sea breeze and marine 4-factor unconstrained solutions (Fig. S7). Besides, the model encountered difficulties in separating hydrocarbon-like organic aerosol (HOA) from cooking-like organic aerosol (COA) for the entire IOP-1 dataset and the continental and marine days. Both $\mathrm{COA}$ and HOA share similar $m / z$ peaks at $27,41,55\left(\mathrm{C}_{n} \mathrm{H}_{2 n-1}^{+}\right)$and $29,43,57$ $\left(\mathrm{C}_{n} \mathrm{H}_{2 n+1}^{+}\right)$that correspond to hydrocarbon fragmentation. Nonetheless, they can be differentiated based on 41/43 and 55/57 ratios, more important for COA (Fröhlich et al., 2015; Mohr et al., 2012), while HOA presents more specific and intense peaks at 69-71. Moreover, under continental influence, they tend to be emitted from the same wind directions corresponding to the urbanized area from northwest to northeast. A good separation with characteristic factor profiles was nonetheless obtained for sea breeze days which present more variable dynamics, with four factors identified, namely HOA, COA, more-oxidized OOA and less-oxidized OOA (mixed with the unknown factor; Fig. S7). The unknown factor presents a rose plot and a daily profile consistent with local emissions from the open waste-burning areas of Gandigal (northwest) and Saly Douté (northeast) and a fish-smoking area also located in the northeast of Mbour (Figs. 1and S8); hence it has been designated as LCOA (local combustion organic aerosol). Since the behavior of $\mathrm{Chl}$ had also been suspected of coming from the same sources, PMF solutions adding the $m / z 36$ signal in the input matrix were investigated, and a solution is presented in Supplement S8, where regional OOA accounts for approximately three-quarters of the OOA and the local OOA accounts for one-quarter. No biomass burning OA (BBOA) profile appeared neither in our unconstrained (up to 10 factors) runs, nor when HOA and COA were themselves constrained. Furthermore, local practices tend to use dry leaves and branches to feed livestock rather than as combustion fuel, and cooking in the urban area is mainly done on gas stoves. Since IOP-1 occurred at the transition between dry and wet seasons, the possibility of long-range emissions of BB from Savannah fire, such as the one observed for example in South Africa (Tiitta et al., 2014) and northern Australia (Milic et al., 2017), or even other BB regional sources, was not discarded at first. Therefore, an average BBOA profile ( $\mathrm{Ng}$ et al., 2011b) was used to constrain the PMF solution with different $a$ values. Using a rather strong constraint of $a=0.3$ led to (i) either stable solutions and a satisfactory BBOA profile, but a mixture between 
LCOA and part of the OOA factor and no COA, or (ii) when LCOA, OOA and COA were well separated, a BBOA profile presenting missing fragments and a high run-to-run instability. Moreover, solutions for more moderate constraints $(a \geq 0.5)$ led to a BBOA profile with unusually low or missing important fragments (such as $m / z 60$ ) and an increasing correlation with COA (Crippa et al., 2013). Besides, the important photochemistry observed on-site coupled with levoglucosan $(m / z 60,73)$ fast reactivity under photo-oxidative conditions (Hennigan et al., 2010) might lead to a fast transformation of BBOA into SOA (which would appear as an OOA factor in our PMF solution). Finally, additional in situ or remote sensing optical instruments specifically implemented for the SHADOW campaign, such as ground-based and airborne sun photometers or the LILAS multiwavelength Mie-Raman lidar (Veselovskii et al., 2016), did not detect the presence of BB aerosol influence. For all these reasons, we decided not to constrain BBOA in our final solutions. In order to refine the solution, and due to the possible specificity of local emissions, the PMF model was run with mild constraints on the primary factor profiles observed in the different unconstrained runs (see Fig. S8), i.e., COA (Crippa et al., 2013) and HOA ( $\mathrm{Ng}$ et al., 2011b), using the $a$-value approach with 30 to $90 \%$ of freedom $(0.3<a<0.9)$ as explained in Canonaco et al. (2013). Indeed HOA are generally emitted by diesel or fuel exhaust, although in rural cities they have also been related to cooking activities (Sun et al., 2012). It has also been reported that African fuels supplied directly by western-company-owned petrol stations present higher levels of sulfur and polyaromatics, and that others are generally a mixture of refinery intermediate products and other (mostly unknown) chemicals, which could hamper the finding of a satisfactory solution. The robustness of the optimal solution was checked by 50 random seed iterations.

A final constrained solution of four factors is presented in Fig. 9 through their respective mass spectra with associated pollution rose plots and daily profiles for continental, sea breeze and marine days. The three primary factors linked to anthropogenic activities, that is to say HOA, COA and LCOA corresponded to 18,30 and $3 \%$ of the organic fraction, respectively. HOA and COA contributions to the OA fraction tend to be more important for continental and sea breeze days with $21-24$ and $24-31 \%$, respectively than for marine days (11-20\%), while LCOA increases slightly from 2 to $7 \%$. The HOA profile is well correlated with $\mathrm{BC}(r=0.79)$ and $m / z 57(r=0.98)$. No specific external tracers have been identified; nonetheless, COA temporal variability appeared to correlate well with $\mathrm{BC}(r=0.73)$. The HOA rose plot shows marked peaks in the directions of the two open wasteburning areas and of the fish-smoking area located northeast of the site on the outskirts of Mbour. HOA and Chl NWR plots are very similar, which suggests either common sources or a mixture of both compounds in the air masses which resulted in a correlation of 0.64 between these two variables. $\mathrm{COA}$ main origin in the northwest corresponds to the touris- tic area of Saly where a number of restaurants are located. $\mathrm{BC}$ concentrations previously linked to $\mathrm{OM}$ species present close correlations with both HOA and COA, but this might be explained by the correlation of 0.82 between both time series, suggesting concomitant emissions between traffic and cooking sources. The variability depicted by their continental and sea breeze daily profiles (Fig. 9b) highlights anthropogenic emissions of COA and HOA, with pronounced peaks during morning and evening ( 0.46 to $0.55 \mu \mathrm{g} \mathrm{m}^{-3}$ ) corresponding to human activities. The COA and HOA profiles present an additional peak after 11:00 LT, reaching a maximum around noon then decreasing after 14:00 LT for continental days. The COA, OOA - and to a much lesser extent, the HOA - sea breeze profiles differed from the continental ones by a delay in the midday peak which rises only after 14:00 LT This difference could be explained by anthropogenic aerosols emitted in the morning, then transported toward the ocean, and carried back on-site through sea breeze phenomena. A similar pattern could have been expected from HOA, but the low concentrations observed suggest faster oxidation processes occurring over the ocean which would contribute to the higher OOA peak. Both COA and HOA factors present low background concentrations during marine days.

As for LCOA, which is a very small fraction of the total OA, the fact that it nonetheless consistently appears in the PMF analysis under both unconstrained and constrained conditions suggests a specific behavior uncorrelated with other sources. Its robustness has been tested under various starting conditions (50 seed iterations) and through rotational ambiguity exploration ( $F$-peak tested between -5 and +5 with a step of 0.5). Despite the fact that $\mathrm{Chl}$ species were presenting similar wind-sector origins, its correlation with LCOA remains low $(r=0.44)$ while LCOA presents higher correlation with $m / z 36$ and 58 ( $r=0.55$ and 0.84 , respectively). This is mainly due to the influence of refractory chloride $(\mathrm{NaCl})$ in our Chl measurements; which has been observed through $m / z 35$ negative values likely resulting from a slow vaporization both during filter and nonfilter measurements (Nuaaman et al., 2015). Nonetheless $m / z 36\left(\mathrm{HCl}^{+}\right.$) was mostly positive $(0.03 \pm 0.03$; see Fig. S9), confirming that non-SS chloride was also detected. Indeed, if sea salt was predominant in LCOA, $\mathrm{NaCl}$ could explain the $m / z 58$ and 60 signals, but one would have expected a maximum on marine days, whereas LCOA pollution rose and NWR plots clearly point toward the local combustion areas already mentioned previously, and also identified in the chloride rose plot (Fig. 8). Although coal combustion used for cooking has been identified as a potential source of chloride emissions (Ianniello et al., 2011; McCulloch et al., 1999), this practice has not been observed in the area. However, chloride species may be emitted from household waste-burning/smoldering, for which particle-bound polychlorinated dibenzo-p-dioxins, dibenzofurans and biphenyls have been measured in previous studies (Gullett et al., 2001; Lemieux et al., 2004; Tue et al., 2016; Zhang et al., 2009), or from sea salt particles subject 

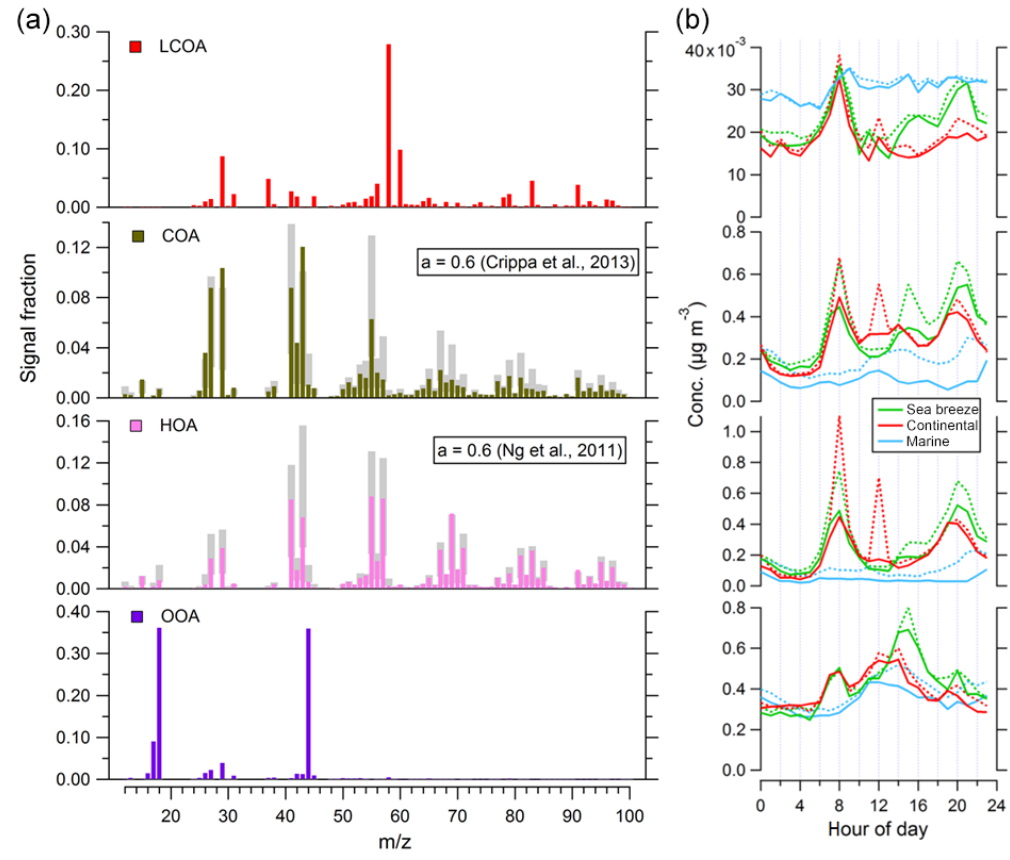

(c) LCOA
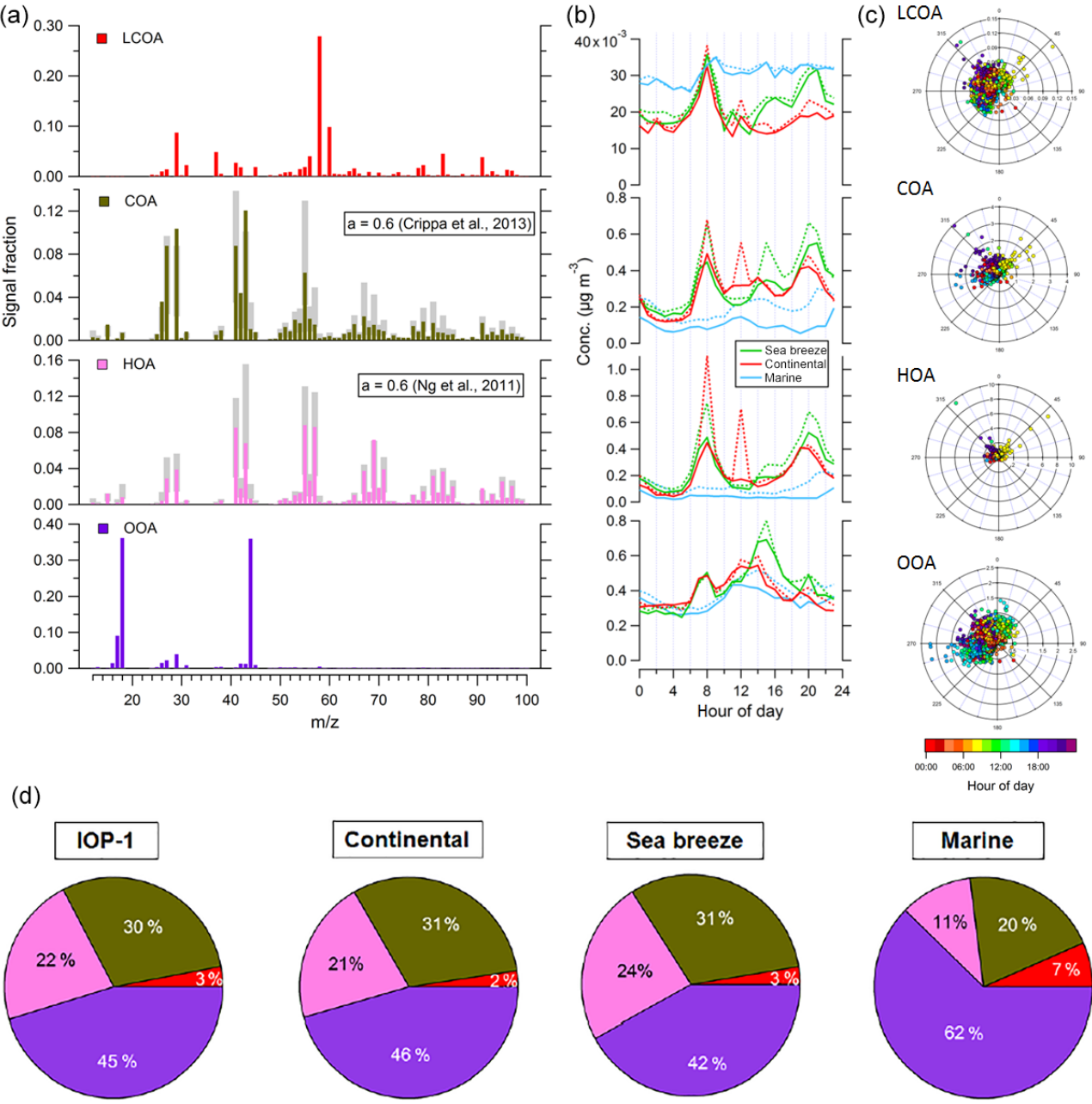

Figure 9. PMF constrained four-factor solution: (a) factor profiles of LCOA, COA, HOA (the two latter constrained) and OOA; (b) corresponding daily cycles according to day types (solid lines: median; dotted lines: average); and (c) pollution rose plots colored by time of day. (d) Average pie charts of the contributions to the total organic fraction for IOP-1, continental, sea breeze and marine days.

to high-temperature combustion processes (since this factor is also observed to a lesser extent in the direction of the fishsmoking area). Besides, the NWR plots of Chl (local influence) and LCOA (both local and regional) rather suggest the presence of chlorinated organics. The PSCF maps identify two possible origins, one clearly from the ocean that could be related to chlorine-driven photo-oxidation processes (Hossaini et al., 2016) and the other linked to air masses carried over Dakar where similar massive anthropogenic emissions from waste-burning could be expected from Mbeubeuss, the largest dump site in Senegal, located $25 \mathrm{~km}$ northeast of Dakar along the coast, which receives $250000 \mathrm{t}$ of garbage per year from the Dakar region (Cissé, 2012).

Additionally, the measured $\mathrm{NH}_{4}$ was higher than that predicted in the directions of the waste-burning areas especially from the northeast (Fig. S4b), also suggesting the formation of nitrogen-containing compounds that could lead to $\mathrm{R}-\mathrm{N}^{+}$or $\mathrm{R}_{-} \mathrm{NO}^{+}$fragments (where $\mathrm{R}$ is a car- bon chain) at these same masses, although high-resolution measurements would be needed to confirm this hypothesis. LCOA also presents its most intense peaks in the morning $\left(0.04 \mu \mathrm{g} \mathrm{m}^{-3}\right)$ with some more moderate peaks in the evening $\left(<0.03 \mu \mathrm{g} \mathrm{m}^{-3}\right)$ for continental and sea breeze daily profiles, characteristics of point sources and/or local emissions. These may be linked to the start of the fires in the morning for the open waste-burning areas and an evening increase of the OM due to a temperature drop that would shift the partitioning of semivolatile species toward the particulate phase. On the contrary its marine profile shows constant but higher concentrations all day long $\left(\sim 0.03 \mu \mathrm{g} \mathrm{m}^{-3}\right)$ with an increase after 08:00 LT, which explains the slightly higher contribution to the OA fraction for the latter.

OOA are often considered as SOA formed through gasconversion processes of volatile organic compounds or photochemical oxidation of primary OA emitted by biogenic (such as plants or algae) and/or anthropogenic sources. The 
hot temperatures and intense solar irradiation encountered in the region enhance these processes and can explain the major contribution ( $45 \%$ ) observed for the OOA factor during IOP1 , and the predominance $(\sim 3 / 4)$ of the more-oxidized fraction in the solution presented in Supplement S8. Its profile showed intense peaks at $m / z 18$ and $44\left(f_{44}=0.36\right)$ and low $43 / 44$ ratios (0.04), which underlined the high level of oxidation characteristic of aged particles, and presented a correlation of 0.88 with the OOA averaged profile reported by $\mathrm{Ng}$ et al. (2011b). In our study, the temporal variability of OOA shows a higher correlation with $\mathrm{NO}_{3}$ than $\mathrm{SO}_{4}(r=0.56$ against $r=0.24)$. As $\mathrm{NO}_{3}$ species are generally semivolatile and associated with less aged air masses (Mohr et al., 2012), OOA might not be only emitted by distant sources, as also suggested by its NWR plot (Fig. S5b). This is highlighted by daily continental and sea breeze profiles rising at around 08:00, noon and 20:00 LT, which emphasizes direct emission of oxidized organic aerosols from anthropogenic activities. Also, it has been mentioned previously that $\mathrm{NO}_{3}$ might not be locally emitted (Figs. 8 and S5b), and since the highest OOA concentrations are associated with wind speeds above $3 \mathrm{~m} \mathrm{~s}^{-1}$, we also attribute a regional origin to this factor. Both the OOA correlation with $\mathrm{NO}_{3}$ and the fact that its daily cycles progressively increase (decrease) with sunrise (sunset) suggest an important and fast photochemistry (Robinson et al., 2007). The OOA rose plot shows rather similar concentrations regardless of wind sectors, even if some concentrations superior to $1.5 \mu \mathrm{g} \mathrm{m}^{-3}$ are connected to western wind influences (Fig. 9). This oceanic origin is also highlighted by OOA sea breeze profile, which shows a maximum of $0.7 \mu \mathrm{g} \mathrm{m}^{-3}$ reached around 15:00 LT (Fig. 9). It indicates that this SOA formation is enhanced during OA transport over the ocean which, under specific atmospheric conditions, can be initiated by chlorine atoms (Hallquist et al., 2009). The OOA PSCF map (Fig. S5c) seems to trace back its origin along the entire western African coast, where shipping emissions could be a major source of organic aerosols. The fact that OOA increase during daytime regardless of day type, as well as their high oxidation level and important contribution to OA, especially during marine days (62\%), supports emissions by regional sources. As shown by the PSCF map (Fig. S5c), higher OOA concentrations are associated with air masses that moved along the coast and could transport oxidized anthropogenic species to the receptor site.

Previous observations of OM from daily filter measurements in the $\mathrm{PM}_{2}$ fraction during AMMA SOP-0 were associated with maximum values of winds coming from the coast (northwest) and the ocean (west; Flament et al., 2011) and attributed to emissions by local sources and cities along the Senegalese coast, suggesting they could originate from wood burning, cooking, and dry leaf or grass burning. Doumbia et al. (2012), only considering biomass burning and fossil fuel combustion as contributing to the absorption measurements during their field campaign in Dakar, also reported $12 \%$ of biomass burning emitted by regional sources against
$88 \%$ by fossil fuel. Our measurements over a period of 3 months at a high time resolution suggest, as mentioned before, that biomass burning from local sources is rather negligible in the Mbour area during the transition period from dry to wet seasons. Cooking, traffic and other local combustion sources such as traditional fish-smoking and household waste-burning have been identified as the primary local anthropogenic sources of OM.

\section{Conclusions}

The deployment of high-time-resolution instruments at the western African coastal site of Mbour (Senegal) over 3 months, encompassing the end of the dry season and the transition period toward the wet season of 2015, allowed the investigation of the temporal variability and chemical composition of the poorly characterized $\mathrm{PM}_{1}$ aerosols in this region. The average NR $\mathrm{PM}_{1}$ concentration $\left(5.4 \mu \mathrm{g} \mathrm{m}^{-3}\right)$ was relatively low, comparable to levels generally reported in rural environments, and was also close to those observed at a South African site. Although marine influence was dominant, various dynamic conditions were encountered during the campaign, with intense dust events, sea breeze phenomena and several anthropogenic episodes $\left(\mathrm{NR} \mathrm{PM}_{1}\right.$ reaching up to $68 \mu \mathrm{g} \mathrm{m}^{-3}$ over a $30 \mathrm{~min}$ period). $\mathrm{PM}_{1}$ concentrations were on average $8.2 \mu \mathrm{g} \mathrm{m}^{-3}$ representing $11 \%$ of $\mathrm{PM}_{10}$, and were dominated by NR species $(71 \%)$, with minor contributions of absorbing species $(9 \%)$. The remaining unaccounted fraction $(20 \%$ on average, up to $75 \%$ during identified dust events) was mainly attributed to mineral dust, strongly suggesting a minor contribution of sea salt in the submicron fraction. Fe concentrations $(5 \%)$ obtained from the deconvolution of absorption measurements were consistent with the dust events observed on-site. Among the species identified in the $\mathrm{PM}_{1}$ fraction, sulfate and organics represented 32 and $31 \%$, respectively, followed by ammonium $(14 \%)$, nitrate $(9 \%)$, BC $(5 \%)$, Fe $(9 \%)$ and $\mathrm{Chl}(<1 \%)$. OM dominated the $\mathrm{NR} \mathrm{PM}_{1}$ fraction when the sampling site was under continental air mass influences (northeastern winds), whereas marine air masses (from western winds) preferentially brought higher concentrations of sulfate species onsite.

Source apportionment of the organic fraction allowed the identification of four types of OA. The organic fraction is composed of a highly oxidized OOA (45\%), whose regional origin is underlined by its important contribution to the organic fraction during marine days $(62 \%)$ but also by its increasing concentration during daytime, with a maximum under sea breeze influence. Nonetheless, its higher correlation with $\mathrm{NO}_{3}$ as well as morning and evening peaks observed for continental and sea breeze daily profiles tend to associate it partially with direct emissions or fast oxidation processes of anthropogenic compounds. Three primary OA linked to anthropogenic activities from nearby sources were 
also identified: HOA (22\%), COA (28\%) and a new factor LCOA (3\%), related to local combustion sources (emissions from open waste-burning and fish-smoking areas), for which a good correlation with particulate chloride $(\mathrm{m} / \mathrm{z} 36)$ was consistently found. Nonrefractory chloride fragments from waste-burning or fish-smoking areas were suggested to originate from local plastic smoldering and flaming processes (for the former) and/or sea salt (for both) submitted to high temperatures under continental influence. This factor, although minor on average, could represent as much as $7 \%$ on a 30 min time period when the air masses were blowing from the local waste-burning areas, and very likely resulted in the concomitant emissions of highly toxic compounds such as dioxins that would require further investigation. Back trajectories also suggest possible distant sources of combustion, with parts of LCOA, OOA and BC associated with processed oceanic air masses which could be influenced by Dakar traffic emissions and waste-burning activities, as well as shipping emissions along the western African coast.

Overall, our study suggests that natural sources strongly influence $\mathrm{PM}_{1}$ levels in Mbour, mainly due to the large influence of marine conditions associated with high sulfate levels and the additional significant influence of desert dust. Our measurements carried out at a suburban site away from megacities allowed us to provide new insight into the complex mixture between local anthropogenic sources and regional background aerosols in the $\mathrm{PM}_{1}$ fraction in western Africa at the end of the dry season.

As shown during this field campaign, at least half of the organic aerosols measured in the submicron fraction are from anthropogenic origins ( $\mathrm{HOA}+\mathrm{COA}+\mathrm{LCOA})$, and we were able to attribute them to specific sources. On the contrary, little is known about the oxygenated fraction - often associated with secondary organic aerosols, which constitutes the other half of OA, and therefore efforts should be directed toward better characterizing SOA precursors (anthropogenic and biogenic) and their concentration levels in western Africa. Moreover, the specific LCOA source puts an emphasis on open waste-burning, which is highly problematic in terms of health issues, and should be addressed through the implementation of waste disposal facilities and an effective waste collection infrastructure.

Data availability. Data from ACSM and Aethalometer instruments are available upon request to the corresponding author, Véronique Riffault. $\mathrm{PM}_{10}$ data can be accessed by request to Anaïs Féron (LISA).

The Supplement related to this article is available online at https://doi.org/10.5194/acp-17-10291-2017supplement.
Competing interests. The authors declare that they have no conflict of interest.

Acknowledgements. Laura-Hélèna Rivellini's $\mathrm{PhD}$ grant and the SHADOW campaign are financially supported by the CaPPA project (Chemical and Physical Properties of the Atmosphere), which is funded by the French National Research Agency (ANR) through the PIA (Programme d'Investissement d'Avenir) under contract "ANR-11-LABX-0005-01", by the Regional Council Hauts-de-France and the European Regional Development Fund (ERDF).

Edited by: James Allan

Reviewed by: three anonymous referees

\section{References}

Allan, J. D., Bower, K. N., Coe, H., Boudries, H., Jayne, J. T., Caragaratna, M. R., Millet, D. B., Goldstein, A. H., Quinn, P. K., Weber, R. J. C. G. L., and Worsnop, D. R.: Submicron aerosol composition at Trinidad Head, California, during ITCT 2K2: Its relationship with gas phase volatile organic carbon and assessment of instrument performance, J. Aerosol Sci., 35, 909-922, https://doi.org/10.1016/j.jaerosci.2004.02.007, 2004.

Bahreini, R., Ervens, B., Middlebrook, A. M., Warneke, C., de Gouw, J. A., DeCarlo, P. F., Jimenez, J. L., Brock, C. A., Neuman, J. A., Ryerson, T. B., Stark, H., Atlas, E., Brioude, J., Fried, A., Holloway, J. S., Peischl, J., Richter, D., Walega, J., Weibring, P., Wollny, A. G. and Fehsenfeld, F. C.: Organic aerosol formation in urban and industrial plumes near Houston and Dallas, Texas, J. Geophys. Res.-Atmos., 114, D00F16, https://doi.org/10.1029/2008JD011493, 2009.

Bond, T. C. and Bergstrom, R. W.: Light Absorption by Carbonaceous Particles: An Investigative Review, Aerosol Sci. Tech., 40, 27-67, https://doi.org/10.1080/02786820500421521, 2006.

Bovchaliuk, V., Goloub, P., Podvin, T., Veselovskii, I., Tanre, D., Chaikovsky, A., Dubovik, O., Mortier, A., Lopatin, A., Korenskiy, M. and Victori, S.: Comparison of aerosol properties retrieved using GARRLiC, LIRIC, and Raman algorithms applied to multi-wavelength lidar and sun/sky-photometer data, Atmos. Meas. Tech., 9, 3391-3405, https://doi.org/10.5194/amt-9-33912016, 2016.

Brauer, M., Amann, M., Burnett, R. T., Cohen, A., Dentener, F., Ezzati, M., Henderson, S. B., Krzyzanowski, M., Martin, R. V., Van Dingenen, R., van Donkelaar, A., and Thurston, G. D.: Exposure Assessment for Estimation of the Global Burden of Disease Attributable to Outdoor Air Pollution, Environ. Sci. Technol., 46, 652-660, https://doi.org/10.1021/es2025752, 2012.

Bressi, M., Cavalli, F., Belis, C. A., Putaud, J.-P., Fröhlich, R., Martins dos Santos, S., Petralia, E., Prévôt, A. S. H., Berico, M., Malaguti, A., and Canonaco, F.: Variations in the chemical composition of the submicron aerosol and in the sources of the organic fraction at a regional background site of the Po Valley (Italy), Atmos. Chem. Phys., 16, 12875-12896, https://doi.org/10.5194/acp-16-12875-2016, 2016.

Brook, R. D., Franklin, B., Cascio, W., Hong, Y., Howard, G., Lipsett, M., Luepker, R., Mittleman, M., Samet, J., and Smith, 
S. C.: Air pollution and cardiovascular disease A statement for healthcare professionals from the expert panel on population and prevention science of the American Heart Association, Circulation, 109, 2655-2671, 2004.

Budisulistiorini, S. H., Canagaratna, M. R., Croteau, P. L., Baumann, K., Edgerton, E. S., Kollman, M. S., Ng, N. L., Verma, V., Shaw, S. L., Knipping, E. M., Worsnop, D. R., Jayne, J. T., Weber, R. J., and Surratt, J. D.: Intercomparison of an Aerosol Chemical Speciation Monitor (ACSM) with ambient fine aerosol measurements in downtown Atlanta, Georgia, Atmos. Meas. Tech., 7, 1929-1941, https://doi.org/10.5194/amt-7-1929-2014, 2014.

Canagaratna, M. R., Jayne, J. T., Jimenez, J. L., Allan, J. D., Alfarra, M. R., Zhang, Q., Onasch, T. B., Drewnick, F., Coe, H., Middlebrook, A., Delia, A., Williams, L. R., Trimborn, A. M., Northway, M. J., DeCarlo, P. F., Kolb, C. E., Davidovits, P., and Worsnop, D. R.: Chemical and microphysical characterization of ambient aerosols with the aerodyne aerosol mass spectrometer, Mass Spectrom. Rev., 26, 185-222, https://doi.org/10.1002/mas.20115, 2007.

Canonaco, F., Crippa, M., Slowik, J. G., Baltensperger, U., and Prévôt, A. S. H.: SoFi, an IGOR-based interface for the efficient use of the generalized multilinear engine (ME2) for the source apportionment: ME-2 application to aerosol mass spectrometer data, Atmos. Meas. Tech., 6, 3649-3661, https://doi.org/10.5194/amt-6-3649-2013, 2013.

Charlson, R. J., Lovelock, J. E., Andreae, M. O., and Warren, S. G.: Oceanic phytoplankton, atmospheric sulphur, cloud albedo and climate, Nature, 326, 655-661, 1987.

Chiapello, I., Bergametti, G., Gomes, L., Chatenet, B., Dulac, F., Pimenta, J., and Suares, E. S.: An additional low layer transport of Sahelian and Saharan dust over the northeastern Tropical Atlantic, Geophys. Res. Lett., 22, 3191-3194, https://doi.org/10.1029/95GL03313, 1995.

Chou, C., Formenti, P., Maille, M., Ausset, P., Helas, G., Harrison, M. and Osborne, S.: Size distribution, shape, and composition of mineral dust aerosols collected during the African Monsoon Multidisciplinary Analysis Special Observation Period 0: Dust and Biomass-Burning Experiment field campaign in Niger, January 2006, J. Geophys. Res.-Atmos., 113, D00C10, https://doi.org/10.1029/2008JD009897, 2008.

Cissé, O.: Les décharges d'ordures en Afrique - Mbeubeuss à Dakar au Sénégal, Karthala, 2012.

Crenn, V., Sciare, J., Croteau, P. L., Verlhac, S., Fröhlich, R., Belis, C. A., Aas, W., Äijälä, M., Alastuey, A., Artiñano, B., Baisnée, D., Bonnaire, N., Bressi, M., Canagaratna, M., Canonaco, F., Carbone, C., Cavalli, F., Coz, E., Cubison, M. J., Esser-Gietl, J. K., Green, D. C., Gros, V., Heikkinen, L., Herrmann, H., Lunder, C., Minguillón, M. C., Mocnik, G., O’Dowd, C. D., Ovadnevaite, J., Petit, J.-E., Petralia, E., Poulain, L., Priestman, M., Riffault, V., Ripoll, A., Sarda-Estève, R., Slowik, J. G., Setyan, A., Wiedensohler, A., Baltensperger, U., Prévôt, A. S. H., Jayne, J. T., and Favez, O.: ACTRIS ACSM intercomparison - Part 1: Reproducibility of concentration and fragment results from 13 individual Quadrupole Aerosol Chemical Speciation Monitors (Q-ACSM) and consistency with co-located instruments, Atmos. Meas. Tech., 8, 5063-5087, https://doi.org/10.5194/amt-8-50632015, 2015.
Crippa, M., El Haddad, I., Slowik, J. G., DeCarlo, P. F., Mohr, C., Heringa, M. F., Chirico, R., Marchand, N., Sciare, J., and Baltensperger, U.: Identification of marine and continental aerosol sources in Paris using high resolution aerosol mass spectrometry, J. Geophys. Res.-Atmos., 118, 1950-1963, 2013.

Cubison, M. J., Ortega, A. M., Hayes, P. L., Farmer, D. K., Day, D., Lechner, M. J., Brune, W. H., Apel, E., Diskin, G. S., Fisher, J. A., Fuelberg, H. E., Hecobian, A., Knapp, D. J., Mikoviny, T., Riemer, D., Sachse, G. W., Sessions, W., Weber, R. J., Weinheimer, A. J., Wisthaler, A., and Jimenez, J. L.: Effects of aging on organic aerosol from open biomass burning smoke in aircraft and laboratory studies, Atmos. Chem. Phys., 11, 12049-12064, https://doi.org/10.5194/acp-11-12049-2011, 2011.

Deboudt, K., Flament, P., Choël, M., Gloter, A., Sobanska, S., and Colliex, C.: Mixing state of aerosols and direct observation of carbonaceous and marine coatings on African dust by individual particle analysis, J. Geophys. Res.-Atmos., 115, D24207, https://doi.org/10.1029/2010jd013921, 2010.

Deboudt, K., Gloter, A., Mussi, A., and Flament, P.: Red-ox speciation and mixing state of iron in individual African dust particles, J. Geophys. Res.-Atmos., 117, D12307, https://doi.org/10.1029/2011jd017298, 2012.

Derimian, Y., Léon, J.-F., Dubovik, O., Chiapello, I., Tanré, D., Sinyuk, A., Auriol, F., Podvin, T., Brogniez, G., and Holben, B. N.: Radiative properties of aerosol mixture observed during the dry season 2006 over M'Bour, Senegal (African Monsoon Multidisciplinary Analysis campaign), J. Geophys. Res.-Atmos., 113, D00C09, https://doi.org/10.1029/2008JD009904, 2008.

Doumbia, E. H. T., Liousse, C., Galy-Lacaux, C., Ndiaye, S. A., Diop, B., Ouafo, M., Assamoi, E. M., Gardrat, E., Castera, P., Rosset, R., Akpo, A., and Sigha, L.: Real time black carbon measurements in West and Central Africa urban sites, Atmos. Environ., 54, 529-537, https://doi.org/10.1016/j.atmosenv.2012.02.005, 2012.

Draxler, R. R. and Hess, G. D.: An overview of the HYSPLIT_4 modeling system of trajectories, dispersion, and deposition, Aust. Meteorol. Mag., 47, 295-308, 1998.

Drinovec, L., Mocnik, G., Zotter, P., Prévôt, A. S. H., Ruckstuhl, C., Coz, E., Rupakheti, M., Sciare, J., Müller, T., Wiedensohler, A., and Hansen, A. D. A.: The "dual-spot" Aethalometer: an improved measurement of aerosol black carbon with realtime loading compensation, Atmos. Meas. Tech., 8, 1965-1979, https://doi.org/10.5194/amt-8-1965-2015, 2015.

Du, W., Sun, Y. L., Xu, Y. S., Jiang, Q., Wang, Q. Q., Yang, W., Wang, F., Bai, Z. P., Zhao, X. D., and Yang, Y. C.: Chemical characterization of submicron aerosol and particle growth events at a national background site (3295 ma.s.1.) on the Tibetan Plateau, Atmos. Chem. Phys., 15, 10811-10824, https://doi.org/10.5194/acp-15-10811-2015, 2015.

EC-JRC/PBL: EDGAR version 4.2, http://edgar.jrc.ec.europa.eu/ (last access: August 2017), 2011.

Fairlie, T. D., Jacob, D. J., Dibb, J. E., Alexander, B., Avery, M. A., van Donkelaar, A., and Zhang, L.: Impact of mineral dust on nitrate, sulfate, and ozone in transpacific Asian pollution plumes, Atmos. Chem. Phys., 10, 3999-4012, https://doi.org/10.5194/acp-10-3999-2010, 2010.

Fialho, P., Hansen, A. D. A., and Honrath, R. E.: Absorption coefficients by aerosols in remote areas: a new approach to decouple dust and black carbon absorption coefficients using seven- 
wavelength Aethalometer data, J. Aerosol Sci., 36, 267-282, https://doi.org/10.1016/j.jaerosci.2004.09.004, 2005.

Fialho, P., Freitas, M. C., Barata, F., Vieira, B., Hansen, A. D. A., and Honrath, R. E.: The Aethalometer calibration and determination of iron concentration in dust aerosols, J. Aerosol Sci., 37, 1497-1506, https://doi.org/10.1016/j.jaerosci.2006.03.002, 2006.

Fialho, P., Cerqueira, M., Pio, C., Cardoso, J., Nunes, T., Custódio, D., Alves, C., Almeida, S. M., Almeida-Silva, M., Reis, M., and Rocha, F.: The application of a multi-wavelength Aethalometer to estimate iron dust and black carbon concentrations in the marine boundary layer of Cape Verde, Atmos. Environ., 97, 136143, https://doi.org/10.1016/j.atmosenv.2014.08.008, 2014.

Fitzgerald, J. W.: Marine aerosols: A review, Atmos. Environ. A-Gen., 25, 533-545, https://doi.org/10.1016/09601686(91)90050-H, 1991.

Flament, P., Deboudt, K., Cachier, H., Châtenet, B., and Mériaux, X.: Mineral dust and carbonaceous aerosols in West Africa: Source assessment and characterization, Atmos. Environ., 45, 3742-3749, https://doi.org/10.1016/j.atmosenv.2011.04.013, 2011.

Fomba, K. W., Müller, K., van Pinxteren, D., Poulain, L., van Pinxteren, M., and Herrmann, H.: Long-term chemical characterization of tropical and marine aerosols at the Cape Verde Atmospheric Observatory (CVAO) from 2007 to 2011, Atmos. Chem. Phys., 14, 8883-8904, https://doi.org/10.5194/acp-148883-2014, 2014.

Formenti, P., Rajot, J. L., Desboeufs, K., Caquineau, S., Chevaillier, S., Nava, S., Gaudichet, A., Journet, E., Triquet, S., Alfaro, S., Chiari, M., Haywood, J., Coe, H., and Highwood, E.: Regional variability of the composition of mineral dust from western Africa: Results from the AMMA SOP0/DABEX and DODO field campaigns, J. Geophys. Res.-Atmos., 113, D00C13, https://doi.org/10.1029/2008jd009903, 2008.

Fröhlich, R., Cubison, M. J., Slowik, J. G., Bukowiecki, N., Canonaco, F., Croteau, P. L., Gysel, M., Henne, S., Herrmann, E., Jayne, J. T., Steinbacher, M., Worsnop, D. R., Baltensperger, U., and Prévôt, A. S. H.: Fourteen months of on-line measurements of the non-refractory submicron aerosol at the Jungfraujoch (3580 ma.s.1.) - chemical composition, origins and organic aerosol sources, Atmos. Chem. Phys., 15, 11373-11398, https://doi.org/10.5194/acp-15-11373-2015, 2015.

Grover, B. D., Kleinman, M., Eatough, N. L., Eatough, D. J., Hopke, P. K., Long, R. W., Wilson, W. E., Meyer, M. B., and Ambs, J. L.: Measurement of total $\mathrm{PM}_{2.5}$ mass (nonvolatile plus semivolatile) with the Filter Dynamic Measurement System tapered element oscillating microbalance monitor, J. Geophys. Res.-Atmos., 110, D07S03, https://doi.org/10.1029/2004JD004995, 2005.

Gullett, B. K., Lemieux, P. M., Lutes, C. C., Winterrowd, C. K., and Winters, D. L.: Emissions of PCDD/F from uncontrolled, domestic waste burning, Chemosphere, 43, 721-725, https://doi.org/10.1016/S0045-6535(00)00425-2, 2001.

Hallquist, M., Wenger, J. C., Baltensperger, U., Rudich, Y., Simpson, D., Claeys, M., Dommen, J., Donahue, N. M., George, C., Goldstein, A. H., Hamilton, J. F., Herrmann, H., Hoffmann, T., Iinuma, Y., Jang, M., Jenkin, M. E., Jimenez, J. L., Kiendler-Scharr, A., Maenhaut, W., McFiggans, G., Mentel, Th. F., Monod, A., Prévôt, A. S. H., Seinfeld, J. H., Surratt, J. D., Szmigielski, R., and Wildt, J.: The formation, properties and im- pact of secondary organic aerosol: current and emerging issues, Atmos. Chem. Phys., 9, 5155-5236, https://doi.org/10.5194/acp9-5155-2009, 2009.

Hand, V. L., Capes, G., Vaughan, D. J., Formenti, P., Haywood, J. M., and Coe, H. C. D.: Evidence of internal mixing of African dust and biomass burning particles by individual particle analysis using electron beam techniques, J. Geophys. Res.-Atmos., 115, D13301, https://doi.org/10.1029/2009jd012938, 2010.

Haywood, J. M., Pelon, J., Formenti, P., Bharmal, N., Brooks, M., Capes, G., Chazette, P., Chou, C., Christopher, S., Coe, H., Cuesta, J., Derimian, Y., Desboeufs, K., Greed, G., Harrison, M., Heese, B., Highwood, E. J., Johnson, B., Mallet, M., Marticorena, B., Marsham, J., Milton, S., Myhre, G., Osborne, S. R., Parker, D. J., Rajot, J. L., Schulz, M., Slingo, A., Tanré, D., and Tulet, P.: Overview of the Dust and Biomass-burning Experiment and African Monsoon Multidisciplinary Analysis Special Observing Period-0, J. Geophys. Res.-Atmos., 113, D00C17, https://doi.org/10.1029/2008jd010077, 2008.

Hennigan, C. J., Sullivan, A. P., Collett, J. L., and Robinson, A. L.: Levoglucosan stability in biomass burning particles exposed to hydroxyl radicals, Geophys. Res. Lett., 37, L09806, https://doi.org/10.1029/2010GL043088, 2010.

Henry, R., Norris, G. A., Vedantham, R., and Turner, J. R.: Source Region Identification Using Kernel Smoothing, Environ. Sci. Technol., 43, 4090-4097, https://doi.org/10.1021/es8011723, 2009.

Holben, B. N., Eck, T. F., Slutsker, I., Tanré, D., Buis, J. P., Setzer, A., Vermote, E., Reagan, J. A., Kaufman, Y. J., Nakajima, T., Lavenu, F., Jankowiak, I., and Smirnov, A.: AERONET - A Federated Instrument Network and Data Archive for Aerosol Characterization, Remote Sens. Environ., 66, 1-16, https://doi.org/10.1016/S0034-4257(98)00031-5, 1998.

Hossaini, R., Chipperfield, M. P., Saiz-Lopez, A., Fernandez, R., Monks, S., Feng, W., Brauer, P., and von Glasow, R.: A global model of tropospheric chlorine chemistry: Organic versus inorganic sources and impact on methane oxidation, J. Geophys. Res.-Atmos., 121, 14271-14297, https://doi.org/10.1002/2016JD025756, 2016.

Ianniello, A., Spataro, F., Esposito, G., Allegrini, I., Hu, M., and Zhu, T.: Chemical characteristics of inorganic ammonium salts in $\mathrm{PM}_{2.5}$ in the atmosphere of Beijing (China), Atmos. Chem. Phys., 11, 10803-10822, https://doi.org/10.5194/acp-11-108032011, 2011.

IPCC: Climate change 2007-the physical science basis: Working group I contribution to the fourth assessment report of the IPCC, Cambridge University Press, 2007.

IPCC: Climate Change 2013: The Physical Science Basis: Working Group I Contribution to the Fifth Assessment Report of the Intergovernmental Panel on Climate Change, Cambridge University Press, 2013.

Journet, E., Balkanski, Y., and Harrison, S. P.: A new data set of soil mineralogy for dust-cycle modeling, Atmos. Chem. Phys., 14, 3801-3816, https://doi.org/10.5194/acp-14-3801-2014, 2014.

Kaly, F., Marticorena, B., Chatenet, B., Rajot, J. L., Janicot, S., Niang, A., Yahi, H., Thiria, S., Maman, A., Zakou, A., Coulibaly, B. S., Coulibaly, M., Koné, I., Traoré, S., Diallo, A., and Ndiaye, T.: Variability of mineral dust concentrations over West Africa monitored by the Sahelian Dust Transect, Atmos. Res., 164-165, 226-241, https://doi.org/10.1016/j.atmosres.2015.05.011, 2015. 
Kandler, K., Schütz, L., Deutscher, C., Ebert, M., Hofmann, H., Jäckel, S., Jaenicke, R., Knippertz, P., Lieke, K., Massling, A., Petzold, A., Schladitz, A., Weinzierl, B., Wiedensohler, A., Zorn, S., and Weinbruch, S.: Size distribution, mass concentration, chemical and mineralogical composition and derived optical parameters of the boundary layer aerosol at Tinfou, Morocco, during SAMUM 2006, Tellus B, 61, 32-50, https://doi.org/10.1111/j.1600-0889.2008.00385.x, 2009.

Karol, Y., Tanré, D., Goloub, P., Vervaerde, C., Balois, J. Y., Blarel, L., Podvin, T., Mortier, A., and Chaikovsky, A.: Airborne sun photometer PLASMA: concept, measurements, comparison of aerosol extinction vertical profile with lidar, Atmos. Meas. Tech., 6, 2383-2389, https://doi.org/10.5194/amt-6-2383-2013, 2013.

Kelly, F. J. and Fussell, J. C.: Size, source and chemical composition as determinants of toxicity attributable to ambient particulate matter, Atmos. Environ., 60, 504-526, 2012.

Lafon, S., Sokolik, I. N., Rajot, J. L., Caquineau, S., and Gaudichet, A.: Characterization of iron oxides in mineral dust aerosols: Implications for light absorption, J. Geophys. Res.-Atmos., 111, D21207, https://doi.org/10.1029/2005JD007016, 2006.

Lanz, V. A., Prévôt, A. S. H., Alfarra, M. R., Weimer, S., Mohr, C., DeCarlo, P. F., Gianini, M. F. D., Hueglin, C., Schneider, J., Favez, O., D'Anna, B., George, C., and Baltensperger, U.: Characterization of aerosol chemical composition with aerosol mass spectrometry in Central Europe: an overview, Atmos. Chem. Phys., 10, 10453-10471, https://doi.org/10.5194/acp-10-104532010, 2010.

Lemieux, P. M., Lutes, C. C., and Santoianni, D. A.: Emissions of organic air toxics from open burning: a comprehensive review, Prog. Energy Combust., 30, 1-32, https://doi.org/10.1016/j.pecs.2003.08.001, 2004.

Léon, J.-F., Derimian, Y., Chiapello, I., Tanré, D., Podvin, T., Chatenet, B., Diallo, A., and Deroo, C.: Aerosol vertical distribution and optical properties over M'Bour $\left(16.96^{\circ} \mathrm{W} ; 14.39^{\circ} \mathrm{N}\right)$, Senegal from 2006 to 2008, Atmos. Chem. Phys., 9, 9249-9261, https://doi.org/10.5194/acp-9-9249-2009, 2009.

Liousse, C., Guillaume, B., Grégoire, J. M., Mallet, M., Galy, C., Pont, V., Akpo, A., Bedou, M., Castéra, P., Dungall, L., Gardrat, E., Granier, C., Konaré, A., Malavelle, F., Mariscal, A., Mieville, A., Rosset, R., Serça, D., Solmon, F., Tummon, F., Assamoi, E., Yoboué, V., and Van Velthoven, P.: Updated African biomass burning emission inventories in the framework of the AMMAIDAF program, with an evaluation of combustion aerosols, Atmos. Chem. Phys., 10, 9631-9646, https://doi.org/10.5194/acp10-9631-2010, 2010.

Marticorena, B., Chatenet, B., Rajot, J. L., Traoré, S., Coulibaly, M., Diallo, A., Koné, I., Maman, A., NDiaye, T., and Zakou, A.: Temporal variability of mineral dust concentrations over West Africa: analyses of a pluriannual monitoring from the AMMA Sahelian Dust Transect, Atmos. Chem. Phys., 10, 8899-8915, https://doi.org/10.5194/acp-10-8899-2010, 2010.

McCulloch, A., Aucott, M. L., Benkovitz, C. M., Graedel, T. E., Kleiman, G., Midgley, P. M., and Li, Y.-F.: Global emissions of hydrogen chloride and chloromethane from coal combustion, incineration and industrial activities: Reactive Chlorine Emissions Inventory, J. Geophys. Res.-Atmos., 104, 8391-8403, https://doi.org/10.1029/1999JD900025, 1999.

Middlebrook, A. M., Bahreini, R., Jimenez, J. L., and Canagaratna, M. R.: Evaluation of Composition-Dependent Col- lection Efficiencies for the Aerodyne Aerosol Mass Spectrometer using Field Data, Aerosol Sci. Tech., 46, 258-271, https://doi.org/10.1080/02786826.2011.620041, 2012.

Milic, A., Mallet, M. D., Cravigan, L. T., Alroe, J., Ristovski, Z. D., Selleck, P., Lawson, S. J., Ward, J., Desservettaz, M. J., PatonWalsh, C., Williams, L. R., Keywood, M. D., and Miljevic, B.: Biomass burning and biogenic aerosols in northern Australia during the SAFIRED campaign, Atmos. Chem. Phys., 17, 39453961, https://doi.org/10.5194/acp-17-3945-2017, 2017.

Minguillón, M. C., Ripoll, A., Pérez, N., Prévôt, A. S. H., Canonaco, F., Querol, X., and Alastuey, A.: Chemical characterization of submicron regional background aerosols in the western Mediterranean using an Aerosol Chemical Speciation Monitor, Atmos. Chem. Phys., 15, 6379-6391, https://doi.org/10.5194/acp-15-6379-2015, 2015.

Mohr, C., DeCarlo, P. F., Heringa, M. F., Chirico, R., Slowik, J. G., Richter, R., Reche, C., Alastuey, A., Querol, X., Seco, R., Peñuelas, J., Jiménez, J. L., Crippa, M., Zimmermann, R., Baltensperger, U., and Prévôt, A. S. H.: Identification and quantification of organic aerosol from cooking and other sources in Barcelona using aerosol mass spectrometer data, Atmos. Chem. Phys., 12, 1649-1665, https://doi.org/10.5194/acp-121649-2012, 2012.

Mortier, A., Goloub, P., Derimian, Y., Tanré, D., Podvin, T., Blarel, L., Deroo, C., Marticorena, B., Diallo, A., and Ndiaye, T.: Climatology of aerosol properties and clear-sky shortwave radiative effects using Lidar and Sun photometer observations in the Dakar site, J. Geophys. Res.-Atmos., 121, 6489-6510, https://doi.org/10.1002/2015JD024588, 2016

Ng, N. L., Herndon, S. C., Trimborn, A., Canagaratna, M. R., Croteau, P. L., Onasch, T. B., Sueper, D., Worsnop, D. R., Zhang, Q., Sun, Y. L., and Jayne, J. T.: An Aerosol Chemical Speciation Monitor (ACSM) for Routine Monitoring of the Composition and Mass Concentrations of Ambient Aerosol, Aerosol Sci. Tech., 45, 780-794, https://doi.org/10.1080/02786826.2011.560211, 2011a.

Ng, N. L., Canagaratna, M. R., Jimenez, J. L., Zhang, Q., Ulbrich, I. M., and Worsnop, D. R.: Real-Time Methods for Estimating Organic Component Mass Concentrations from Aerosol Mass Spectrometer Data, Environ. Sci. Technol., 45, 910-916, https://doi.org/10.1021/es102951k, 2011b.

Nuaaman, I., Li, S.-M., Hayden, K. L., Onasch, T. B., Massoli, P., Sueper, D., Worsnop, D. R., Bates, T. S., Quinn, P. K., and McLaren, R.: Separating refractory and non-refractory particulate chloride and estimating chloride depletion by aerosol mass spectrometry in a marine environment, Atmos. Chem. Phys. Discuss., 15, 2085-2118, https://doi.org/10.5194/acpd-15-20852015, 2015.

Ocean biology processing group: MODIS Aqua Level 3 Global Daily Mapped $4 \mathrm{~km}$ Chlorophyll $a$, Ver. 6, PO.DAAC, CA, USA., available at: https://neo.sci.gsfc.nasa.gov/view. php?datasetId=MY1DMM_CHLORA\&year=2015 (last access: 14 June 2017), 2003.

Osborne, S. R., Johnson, B. T., Haywood, J. M., Baran, A. J., Harrison, M. A. J., and McConnell, C. L.: Physical and optical properties of mineral dust aerosol during the Dust and Biomassburning Experiment, J. Geophys. Res.-Atmos., 113, D00C03, https://doi.org/10.1029/2007jd009551, 2008. 
Ovadnevaite, J., Ceburnis, D., Canagaratna, M., Berresheim, H., Bialek, J., Martucci, G., Worsnop, D. R., and O'Dowd, C.: On the effect of wind speed on submicron sea salt mass concentrations and source fluxes, J. Geophys. Res.-Atmos., 117, D16201, https://doi.org/10.1029/2011JD017379, 2012.

Paatero, P. and Tapper, U.: Positive matrix factorization: A non-negative factor model with optimal utilization of error estimates of data values, Environmetrics, 5, 111-126, https://doi.org/10.1002/env.3170050203, 1994.

Paris, R., Desboeufs, K. V., Formenti, P., Nava, S., and Chou, C.: Chemical characterisation of iron in dust and biomass burning aerosols during AMMA-SOP0/DABEX: implication for iron solubility, Atmos. Chem. Phys., 10, 4273-4282, https://doi.org/10.5194/acp-10-4273-2010, 2010.

Parworth, C., Fast, J., Mei, F., Shippert, T., Sivaraman, C., Tilp, A., Watson, T., and Zhang, Q.: Long-term measurements of submicrometer aerosol chemistry at the Southern Great Plains (SGP) using an Aerosol Chemical Speciation Monitor (ACSM), Atmos. Environ., 106, 43-55, https://doi.org/10.1016/j.atmosenv.2015.01.060, 2015.

Petit, J.-E., Favez, O., Sciare, J., Canonaco, F., Croteau, P., Mocnik, G., Jayne, J., Worsnop, D., and Leoz-Garziandia, E.: Submicron aerosol source apportionment of wintertime pollution in Paris, France by double positive matrix factorization $\left(\mathrm{PMF}^{2}\right) \mathrm{us}-$ ing an aerosol chemical speciation monitor (ACSM) and a multiwavelength Aethalometer, Atmos. Chem. Phys., 14, 1377313787, https://doi.org/10.5194/acp-14-13773-2014, 2014.

Petit, J.-E., Favez, O., Sciare, J., Crenn, V., Sarda-Estève, R., Bonnaire, N., Mocnik, G., Dupont, J.-C., Haeffelin, M., and LeozGarziandia, E.: Two years of near real-time chemical composition of submicron aerosols in the region of Paris using an Aerosol Chemical Speciation Monitor (ACSM) and a multiwavelength Aethalometer, Atmos. Chem. Phys., 15, 2985-3005, https://doi.org/10.5194/acp-15-2985-2015, 2015.

Petit, J.-E., Favez, O., Albinet, A., and Canonaco, F.: A user-friendly tool for comprehensive evaluation of the geographical origins of atmospheric pollution: Wind and trajectory analyses, Environ. Model. Softw., 88, 183-187, https://doi.org/10.1016/j.envsoft.2016.11.022, 2017.

Pio, C. A., Cardoso, J., Cerqueira, M. A., Calvo, A., Nunes, T. V., Alves, C. A., Custodio, D., Almeida, S. M., and Silva, M. A.: Seasonal variability of aerosol concentration and size distribution in Cape Verde using a continuous aerosol optical spectrometer, Front. Environ. Sci., 2, 2-15, https://doi.org/10.3389/fenvs.2014.00015, 2014.

Polissar, A. V., Hopke, P. K., and Poirot, R. L.: Atmospheric Aerosol over Vermont: Chemical Composition and Sources, Environ. Sci. Technol., 35, 4604-4621, https://doi.org/10.1021/es0105865, 2001.

Prenni, A. J., Day, D. E., Evanoski-Cole, A. R., Sive, B. C., Hecobian, A., Zhou, Y., Gebhart, K. A., Hand, J. L., Sullivan, A. P., Li, Y., Schurman, M. I., Desyaterik, Y., Malm, W. C., Collett Jr., J. L., and Schichtel, B. A.: Oil and gas impacts on air quality in federal lands in the Bakken region: an overview of the Bakken Air Quality Study and first results, Atmos. Chem. Phys., 16, 14011416, https://doi.org/10.5194/acp-16-1401-2016, 2016.

Redelsperger, J.-L., Thorncroft, C. D., Diedhiou, A., Lebel, T., Parker, D. J., and Polcher, J.: African Monsoon Multidisciplinary Analysis: An International Research Project and
Field Campaign, B. Am. Meteorol. Soc., 87, 1739-1746, https://doi.org/10.1175/BAMS-87-12-1739, 2006.

Ripoll, A., Minguillón, M. C., Pey, J., Jimenez, J. L., Day, D. A., Sosedova, Y., Canonaco, F., Prévôt, A. S. H., Querol, X., and Alastuey, A.: Long-term real-time chemical characterization of submicron aerosols at Montsec (southern Pyrenees, $1570 \mathrm{~m}$ a.s.1.), Atmos. Chem. Phys., 15, 2935-2951, https://doi.org/10.5194/acp-15-2935-2015, 2015.

Robinson, A. L., Donahue, N. M., Shrivastava, M. K., Weitkamp, E. A., Sage, A. M., Grieshop, A. P., Lane, T. E., Pierce, J. R., and Pandis, S. N.: Rethinking Organic Aerosols: Semivolatile Emissions and Photochemical Aging, Science, 315, 1259-1262, https://doi.org/10.1126/science.1133061, 2007.

Salcedo, D., Onasch, T. B., Dzepina, K., Canagaratna, M. R., Zhang, Q., Huffman, J. A., DeCarlo, P. F., Jayne, J. T., Mortimer, P., Worsnop, D. R., Kolb, C. E., Johnson, K. S., Zuberi, B., Marr, L. C., Volkamer, R., Molina, L. T., Molina, M. J., Cardenas, B., Bernabé, R. M., Márquez, C., Gaffney, J. S., Marley, N. A., Laskin, A., Shutthanandan, V., Xie, Y., Brune, W., Lesher, R., Shirley, T., and Jimenez, J. L.: Characterization of ambient aerosols in Mexico City during the MCMA-2003 campaign with Aerosol Mass Spectrometry: results from the CENICA Supersite, Atmos. Chem. Phys., 6, 925-946, https://doi.org/10.5194/acp-6925-2006, 2006.

Sandradewi, J., Prévôt, A. S. H., Szidat, S., Perron, N., Alfarra, M. R., Lanz, V. A., Weingartner, E., and Baltensperger, U.: Using Aerosol Light Absorption Measurements for the Quantitative Determination of Wood Burning and Traffic Emission Contributions to Particulate Matter, Environ. Sci. Technol., 42, 33163323, https://doi.org/10.1021/es702253m, 2008.

Savoie, D. L., Prospero, J. M., and Saltzman, E. S.: Non-sea-salt sulfate and nitrate in trade wind aerosols at Barbados: Evidence for long-range transport, J. Geophys. Res.-Atmos., 94, 5069-5080, https://doi.org/10.1029/JD094iD04p05069, 1989.

Schlag, P., Kiendler-Scharr, A., Blom, M. J., Canonaco, F., Henzing, J. S., Moerman, M., Prévôt, A. S. H., and Holzinger, R.: Aerosol source apportionment from 1-year measurements at the CESAR tower in Cabauw, the Netherlands, Atmos. Chem. Phys., 16, 8831-8847, https://doi.org/10.5194/acp-16-8831-2016, 2016.

Schurman, M. I., Lee, T., Desyaterik, Y., Schichtel, B. A., Kreidenweis, S. M. and Collett Jr., J. L.: Transport, biomass burning, and in-situ formation contribute to fine particle concentrations at a remote site near Grand Teton National Park, Atmos. Environ., 112, 257-268, https://doi.org/10.1016/j.atmosenv.2015.04.043, 2015.

Slingo, A., Bharmal, N. A., Robinson, G. J., Settle, J. J., Allan, R. P., White, H. E., Lamb, P. J., Lélé, M. I., Turner, D. D., McFarlane, S., Kassianov, E., Barnard, J., Flynn, C. and Miller, M.: Overview of observations from the RADAGAST experiment in Niamey, Niger: Meteorology and thermodynamic variables, J. Geophys. Res.-Atmos., 113, D00E01, https://doi.org/10.1029/2008JD009909, 2008.

Sun, C., Lee, B. P., Huang, D., Jie Li, Y., Schurman, M. I., Louie, P. K. K., Luk, C., and Chan, C. K.: Continuous measurements at the urban roadside in an Asian megacity by Aerosol Chemical Speciation Monitor (ACSM): particulate matter characteristics during fall and winter seasons in Hong Kong, Atmos. Chem. Phys., 16, 1713-1728, https://doi.org/10.5194/acp-16-1713-2016, 2016.

Sun, Y., Wang, Z., Dong, H., Yang, T., Li, J., Pan, X., Chen, P., and Jayne, J. T.: Characterization of summer organic 
and inorganic aerosols in Beijing, China with an Aerosol Chemical Speciation Monitor, Atmos. Environ., 51, 250-259, https://doi.org/10.1016/j.atmosenv.2012.01.013, 2012.

Sun, Y. L., Wang, Z. F., Fu, P. Q., Yang, T., Jiang, Q., Dong, H. B., Li, J., and Jia, J. J.: Aerosol composition, sources and processes during wintertime in Beijing, China, Atmos. Chem. Phys., 13, 4577-4592, https://doi.org/10.5194/acp-13-4577-2013, 2013.

Tiitta, P., Vakkari, V., Croteau, P., Beukes, J. P., van Zyl, P. G., Josipovic, M., Venter, A. D., Jaars, K., Pienaar, J. J., Ng, N. L., Canagaratna, M. R., Jayne, J. T., Kerminen, V.-M., Kokkola, H., Kulmala, M., Laaksonen, A., Worsnop, D. R., and Laakso, L.: Chemical composition, main sources and temporal variability of $\mathrm{PM}_{1}$ aerosols in southern African grassland, Atmos. Chem. Phys., 14, 1909-1927, https://doi.org/10.5194/acp-141909-2014, 2014.

Titos, G., Lyamani, H., Pandolfi, M., Alastuey, A., and Alados-Arboledas, L.: Identification of fine $\left(\mathrm{PM}_{1}\right)$ and coarse $\left(\mathrm{PM}_{10-1}\right)$ sources of particulate matter in an urban environment, Atmos. Environ., 89, 593-602, https://doi.org/10.1016/j.atmosenv.2014.03.001, 2015.

Topping, D., Coe, H., McFiggans, G., Burgess, R., Allan, J., Alfarra, M. R., Bower, K., Choularton, T. W., Decesari, S., and Facchini, M. C.: Aerosol chemical characteristics from sampling conducted on the Island of Jeju, Korea during ACE Asia, Atmos. Environ., 38, 2111-2123, https://doi.org/10.1016/j.atmosenv.2004.01.022, 2004.

Tue, N. M., Goto, A., Takahashi, S., Itai, T., Asante, K. A., Kunisue, T., and Tanabe, S.: Release of chlorinated, brominated and mixed halogenated dioxin-related compounds to soils from open burning of e-waste in Agbogbloshie (Accra, Ghana), J. Hazard. Mater., 302, 151-157, https://doi.org/10.1016/j.jhazmat.2015.09.062, 2016.

Val, S., Liousse, C., Doumbia, E. H. T., Galy-Lacaux, C., Cachier, H., Marchand, N., Badel, A., Gardrat, E., Sylvestre, A., and Baeza-Squiban, A.: Physico-chemical characterization of African urban aerosols (Bamako in Mali and Dakar in Senegal) and their toxic effects in human bronchial epithelial cells: description of a worrying situation, Part Fibre Toxicol., 10, 10, https://doi.org/10.1186/1743-8977-10-10, 2013.

Veselovskii, I., Goloub, P., Podvin, T., Bovchaliuk, V., Derimian, Y., Augustin, P., Fourmentin, M., Tanre, D., Korenskiy, M., Whiteman, D. N., Diallo, A., Ndiaye, T., Kolgotin, A., and Dubovik, O.: Retrieval of optical and physical properties of African dust from multiwavelength Raman lidar measurements during the SHADOW campaign in Senegal, Atmos. Chem. Phys., 16, 70137028, https://doi.org/10.5194/acp-16-7013-2016, 2016. von der Weiden, S.-L., Drewnick, F., and Borrmann, S.: Particle Loss Calculator - a new software tool for the assessment of the performance of aerosol inlet systems, Atmos. Meas. Tech., 2, 479-494, https://doi.org/10.5194/amt-2-479-2009, 2009.

Weingartner, E., Saathoff, H., Schnaiter, M., Streit, N., Bitnar, B., and Baltensperger, U.: Absorption of light by soot particles: determination of the absorption coefficient by means of aethalometers, J. Aerosol Sci., 34, 1445-1463, https://doi.org/10.1016/S0021-8502(03)00359-8, 2003.

WHO - World Health Organization: Air quality guidelines for particulate matter, ozone, nitrogen dioxide and sulfur dioxide: Global update 2005: summary of risk assessment, Geneva, Switzerland, 2006.

Zhang, Q., Worsnop, D. R., Canagaratna, M. R., and Jimenez, J. L.: Hydrocarbon-like and oxygenated organic aerosols in Pittsburgh: insights into sources and processes of organic aerosols, Atmos. Chem. Phys., 5, 3289-3311, https://doi.org/10.5194/acp-5-32892005, 2005.

Zhang, Q., Jimenez, J. L., Canagaratna, M. R., Allan, J. D., Coe, H., Ulbrich, I., Alfarra, M. R., Takami, A., Middlebrook, A. M., Sun, Y. L., Dzepina, K., Dunlea, E., Docherty, K., DeCarlo, P. F., Salcedo, D., Onasch, T., Jayne, J. T., Miyoshi, T., Shimono, A., Hatakeyama, S., Takegawa, N., Kondo, Y., Schneider, J., Drewnick, F., Borrmann, S., Weimer, S., Demerjian, K., Williams, P., Bower, K., Bahreini, R., Cottrell, L., Griffin, R. J., Rautiainen, J., Sun, J. Y., Zhang, Y. M., and Worsnop, D. R.: Ubiquity and dominance of oxygenated species in organic aerosols in anthropogenically-influenced Northern Hemisphere midlatitudes, Geophys. Res. Lett., 34, L13801, https://doi.org/10.1029/2007GL029979, 2007.

Zhang, S., Riffault, V., Dusanter, S., Augustin, P., Fourmentin, M., and Delbarre, H.: One year of real-time chemical speciation measurements of submicron particulate matter $\left(\mathrm{PM}_{1}\right)$ at a French coastal site: assessment of industrial and shipping emissions, in preparation, 2017.

Zhang, Y., Wang, X., Chen, H., Yang, X., Chen, J., and Allen, J. O.: Source apportionment of leadcontaining aerosol particles in Shanghai using single particle mass spectrometry, Chemosphere, 74, 501-507, https://doi.org/10.1016/j.chemosphere.2008.10.004, 2009. 